\title{
A Scoping Review of the Health of African Immigrant and Refugee Children
}

\author{
Bukola Salami $^{1, *(\mathbb{D})}$, Higinio Fernandez-Sanchez ${ }^{1}\left(\mathbb{0}\right.$, Christa Fouche $^{2}$, Catrin Evans ${ }^{3}\left(\mathbb{C}\right.$, Lindiwe Sibeko ${ }^{4}$, \\ Mia Tulli ${ }^{1}$, Ashley Bulaong ${ }^{1}$, Stephen Owusu Kwankye ${ }^{5}$, Mary Ani-Amponsah ${ }^{6}{ }^{\circledR}$, Philomina Okeke-Ihejirika ${ }^{7}$,

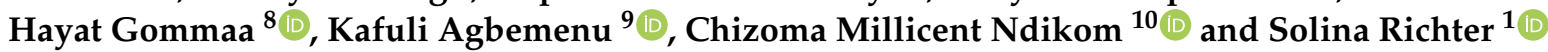

1 Faculty of Nursing, University of Alberta, 1140587 Avenue, Edmonton, AB T6G 0Z7, Canada; higinio@ualberta.ca (H.F.-S.); tulli@ualberta.ca (M.T.); abulaong@ualberta.ca (A.B.); solina.richter@ualberta.ca (S.R.)

2 Faculty of Education and Social Work, University of Auckland, Private Bag 92019, Auckland 1142, New Zealand; c.fouche@auckland.ac.nz

3 School of Health Sciences, University of Nottingham, University Park, Nottingham NG7 2RD, UK; Catrin.Evans@nottingham.ac.uk

4 Department of Nutrition, School of Public Health and Health Sciences, University of Massachusetts, 204 Chenoweth Laboratory, Amherst, MA 01003-9282, USA; lsibeko@umass.edu

5 Regional Institute for Population Studies, University of Ghana, P.O. Box LG 96, Legon, Accra GA184, Ghana skwankye@ug.edu.gh

6 School of Nursing, University of Ghana, P.O. Box LG 43, Legon, Accra GA184, Ghana; mnkansah@ualberta.ca

7 Department of Women's and Gender Studies, University of Alberta, Edmonton, AB T6G 2E7, Canada; pokeke@ualberta.ca

updates

Citation: Salami, B.;

Fernandez-Sanchez, H.; Fouche, C.;

Evans, C.; Sibeko, L.; Tulli, M.;

Bulaong, A.; Kwankye, S.O.;

Ani-Amponsah, M.; Okeke-Ihejirika,

P.; et al. A Scoping Review of the Health of African Immigrant and Refugee Children. Int. J. Environ. Res. Public Health 2021, 18, 3514. https:// doi.org/10.3390/ijerph18073514

Academic Editor: Paul B. Tchounwou

Received: 25 February 2021

Accepted: 22 March 2021

Published: 28 March 2021

Publisher's Note: MDPI stays neutral with regard to jurisdictional claims in published maps and institutional affiliations.

Copyright: (c) 2021 by the authors. Licensee MDPI, Basel, Switzerland. This article is an open access article distributed under the terms and conditions of the Creative Commons Attribution (CC BY) license (https:// creativecommons.org/licenses/by/ $4.0 /)$
8 Department of Nursing Science, Ahmadu Bello University, Sokoto Road, PMB 06, Zaria 810107, Nigeria; h_gommaa@yahoo.com

9 School of Nursing, The State University of New York (SUNY), University at Buffalo, 3435 Main Street, Buffalo, NY 14214, USA; agbemenu@buffalo.edu

10 Department of Nursing, University of Ibadan, Ibadan 200284, Nigeria; cmndikom@gmail.com

* Correspondence: bukola.salami@ualberta.ca

Abstract: Migration is a growing phenomenon around the world, including within the African continent. Many migrants, especially African children, face challenges related to health and social inclusion and can face increased health risks. A systematic scoping review of available literature on the health of African migrant children across the globe was conducted to offer insight into these health risks. The review was conducted over a 15-month period from January 2019 to April 2020, yielding 6602 articles once duplicates were removed. This search included electronic databases, reference lists of articles reviewed, and searches of libraries of relevant organisations. A total of 187 studies met the inclusion criteria, of which 159 were quantitative, 22 were qualitative, and 6 used mixed methods. The findings reveal decreased health in this population in areas of nutrition, infectious diseases, mental health, birth outcomes, sexual and reproductive health, physical and developmental health, parasitic infections, oral health, respiratory health, preventative health, endocrine disorders, health care services, and haematological conditions. The findings offer insights into factors influencing the health of African immigrant and refugee children. Further studies, especially qualitative studies, are needed to determine barriers to service access after migration and to investigate other underexplored and overlooked health concerns of African migrant children, including pneumonia and child maltreatment.

Keywords: migration; health; child health; Africa

\section{Introduction}

Global migration is a growing phenomenon heavily influenced by global economic, social, political, and technological transformations, and climate change [1]. The International Organisation for Migration [1] estimates that of some 272 million international migrants, 
of which approximately 31 million (13.9\%) are children ages 0 to 18 years old. Migration commonly follows a pattern of movement from low- to higher-income countries, including within the African continent, which has a growing number of migrants. In 2019, there were approximately 39.5 million African migrants, of which 21 million moved within African countries and 18.5 million migrated outside of Africa [1]. The vast majority of migrants are labour migrants.

While migrants make significant contributions to the economic, socio-cultural, and political growth of their destination countries, they also face challenges related to health and social inclusion. Migration can lead to increased health risks, but also potentially to improved health for those who seek safety, including children [1]. Differences and complexities are related to the health of migrants, including issues that cross racial, ethnic, and generational lines. While research has identified a health advantage for economic immigrants, compared to the domestic population of host countries (a phenomenon known as the healthy immigrant effect), the case is not the same for refugees who flee their countries for safety [2-4]. Research also points to poorer mental health among second-generation immigrant children, compared to first-generation immigrants [5,6]. First-generation immigrant children have been shown to demonstrate better mental health than non-immigrant children [5], which is evidence of the healthy immigrant effect [6]. However, favourable health status among immigrants may be due to the fact that previous research has often combined all immigrant children without considering the differences among them. For instance, immigrant children and youth from certain regions of Africa, especially those who are refugees, have poorer mental health status than non-immigrant children [7]. The distinct health vulnerabilities faced by African immigrant children create a need to address the mental health of this population. This paper presents the results of a scoping review of the literature on the health of African migrant children (AMC).

Health is a human right that can influence the ability to enjoy other rights. However, many African migrants experience health challenges upon settlement in a new country [8,9]. Pre-migration factors (e.g., experience of trauma) and post-migration challenges (e.g., access to health care) contribute to the health of immigrants in destination countries $[1,10]$. A scoping review that included 14 articles found that culture, religious beliefs, linguistic barriers, and barriers accessing health care contributed to the health of African immigrants in the United States [8]. Barriers to access to health care for this population include cost, health system complexity, lack of culturally competent health providers, long wait times, and discrimination $[8,11]$. Moreover, despite an overall higher level of education than native-born populations and other immigrant groups, African migrants to high-income countries often experience a higher rate of poverty, a key social determinant of health [12]. Evidence suggests that income is a major contributor to immigrant health [13]. As is the case with other marginalised groups, social determinants of health play a critical role in the decline of immigrant health after a period of time in the destination country [13], and this is especially true for African immigrants [9]. The poor social outcomes of immigrants extend to the health of their children, which is particularly the case for African migrants who often have to juggle multiple jobs to earn the income necessary to meet the health needs of their children [14]. Poor social outcomes of immigrant parents impose intergenerational consequences, whereby second-generation immigrant children experience poorer health outcomes than their parents $[15,16]$; again, this is most evident in the case of African immigrants.

Immigrant and refugee children experience several health challenges upon arrival in their destination countries. Despite the fact that these children's health should be protected as a human right, overwhelming evidence from systematic reviews indicates refugee children experience poor mental health status, especially post-traumatic stress [17-19]. Pre-migration experience and post-migration stress contribute to the mental health of refugee children [17]. Social support, sense of belonging, and connection to home culture can improve resilience in this population and contribute to improved mental health [20]. Immigrant and refugee children also experience physical health problems, including 
anaemia, haemoglobinopathies, chronic hepatitis B, latent tuberculosis infection, intestinal infection, oral health problems, vitamin D deficiency, wasting, and stunting [21,22]. While several systematic reviews have been published on the health of immigrant and refugee children, we found none that focus on the health of African immigrant children; previous reviews often combined African immigrant children with other immigrants and lacked an in-depth analysis of their particular vulnerabilities. Thus, a review of existing studies is necessary to fill this gap. A review focusing on African immigrant children's health is particularly important given the poor health status of African immigrants [7,8]. Further study of the health status of African immigrants is also needed to ensure and inform the development of relevant interventions. Interventions should involve the participation of, and centre the voices of, African migrant and refugee children.

\section{Materials and Methods}

A scoping review is appropriate for identifying existing research activity on a particular topic and key research gaps $[23,24]$. We conducted a systematic scoping review over a 15-month period from January 2019 to April 2020. This review followed the five-stage approach to scoping reviews as outlined by Arksey and O'Malley [25]: developing the research question; identifying the relevant studies; selecting the articles; data charting and data extraction; and collating, summarizing, and reporting the results. The review has been reported following the Preferred Reporting Items for Systematic Reviews and Meta-Analyses (PRISMA), Extension for Scoping Review Guidelines [26].

Stage 1 aimed to refine questions on the body of evidence related to African immigrant and refugee children. Our research questions were as follows:

1. What is the scope, range, and nature of evidence on the health of African migrant children?

2. What is known from the existing literature on the health of African migrant children?

Stage 2 involved identifying the relevant studies. The search included electronic databases, a reference list of articles reviewed, and searches of libraries of relevant organisations. The following databases were searched on 21 January 2019 by a health science librarian: Medline, Embase, Ovid Global Health, Ovid PsycInfo, Cochrane Library, CINAHL, SocIndex; EBSCO Child Development and Adolescent Studies, ProQuest Sociological Abstracts, and ProQuest Dissertations and Theses Global. The search terms used represent associated keyword combinations of child health, immigrant health, and Africa (Table 1: Search Terms). A total of 12,720 records were identified and retrieved, and 6602 records remained after duplicates were removed. These articles were exported into Covidence, an online software that works in collaboration with Cochrane to enhance the selection and completion of systematic reviews. This software allows for independent reviewers to screen records based on inclusion criteria. Results were checked by two research assistants.

Table 1. Search Terms.

\begin{tabular}{|c|c|}
\hline & Keywords Used \\
\hline Child Health & $\begin{array}{l}\text { Adolescent health services, child care, infant care, infant, newborn, infant health, } \\
\text { child welfare, infant welfare, child nutrition disorders, infant nutrition disorders, } \\
\text { child nutritional physiological phenomena, adolescent nutritional physiological } \\
\text { phenomena, adolescent development, adolescent health, adolescent medicine, } \\
\text { adolescent psychiatry, psychology, adolescent or child psychiatry, adolescent } \\
\text { development, child development, psychology, child, children, childhood, infant } \\
\text { *, newborn }{ }^{*} \text {, neonate }{ }^{*} \text {, baby, babies, preschool } \text {, toddler }^{*} \text {, adolescen }{ }^{*} \text {, teen } \\
\text { youth }\end{array}$ \\
\hline Immigrant & Emigrants, refugee ${ }^{*}$, immigra ${ }^{*}$, asylum seeker ${ }^{*}$, migrant ${ }^{*}$, displace ${ }^{*}$, transient ${ }^{*}$ \\
\hline Africa & African * and the name of each African country \\
\hline
\end{tabular}

Stage 3 involved article selection. Two research assistants independently selected and reviewed each article that met the following inclusion criteria: (1) focus on the health of 
African child migrants and refugees; (2) child's age is between 0 and 18 years old; (3) child is either a first-generation or second-generation immigrant; (4) report original research studies; and (5) data are on children who crossed an international border. We excluded articles related to internally displaced children and internal migrants because they are still located within the same country and policy jurisdiction. We also excluded articles on African American children (in which information was not provided on whether they are immigrants), African Caribbean children, and articles that focused on the challenges of parents without sufficient information on the health of the child. We also excluded articles that did not have disaggregated data on African immigrant children (e.g., those in which data on African immigrants were combined with other immigrants). All publications such as conference abstracts, literature reviews, book chapters, brief reports or case reports, posters, study protocols, and theses that did not qualify as an empirical output were also excluded (see list in the flow chart). Screening of titles and abstracts and excluding articles resulted in a remaining 615 articles. Only articles published in English and Spanish were included. We screened the full text of all 615 and rejected another 426 based on the inclusion criteria to arrive at 187 articles used in the analysis (see Figure 1 for PRISMA flow chart). At each stage, disagreements between the two reviewers were resolved by consensus or by a third reviewer.

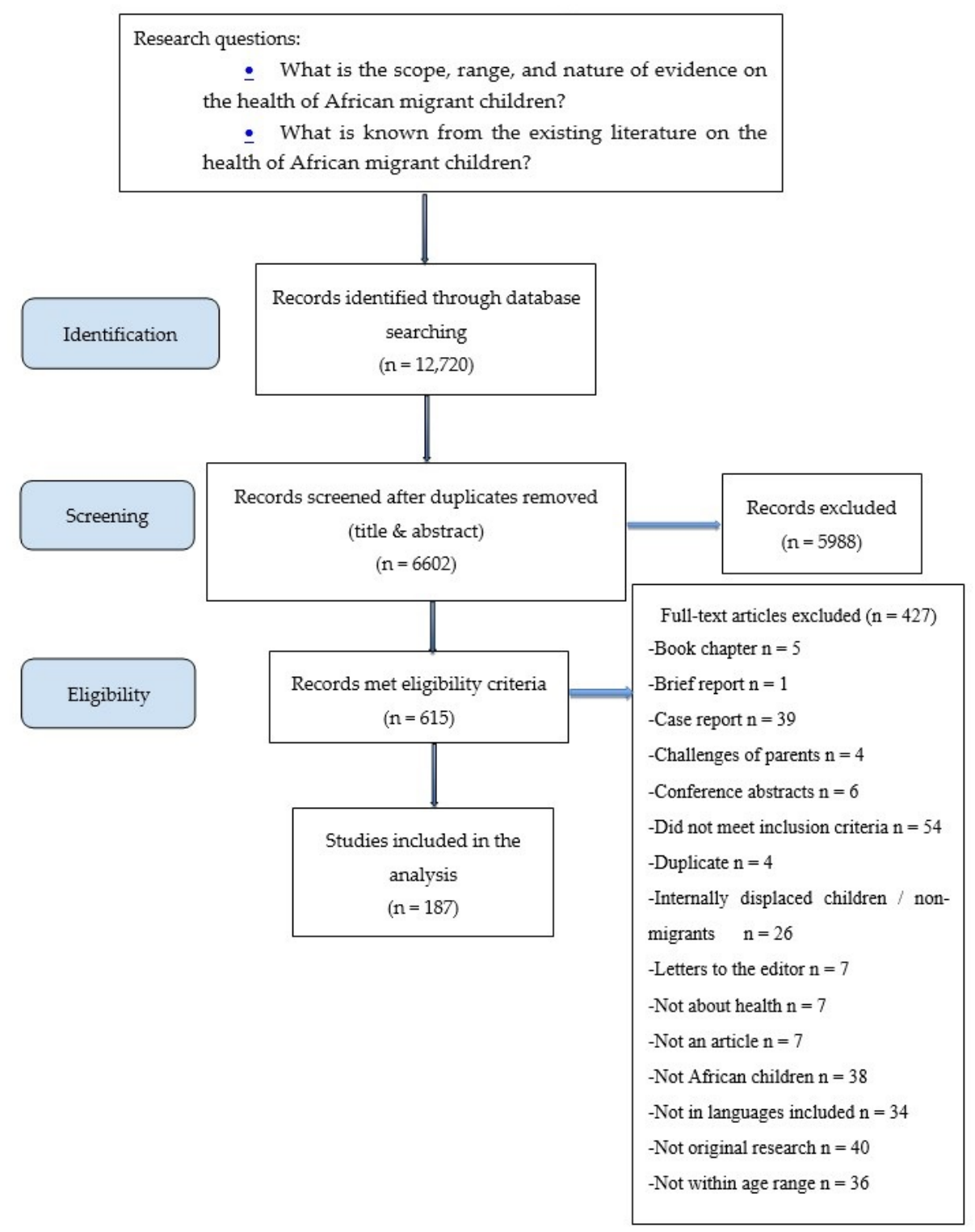

Figure 1. Flow Chart. 
Stage 4 involved data charting and data extraction. The following information was extracted from each of the 187 articles: author(s) name, year of publication, research questions or objectives, theoretical framework, method (sampling, sample size, age of the child, data source (parent vs. child vs. health professional vs. medical records vs. clinical assessment vs. laboratory tests), clinical area of focus (e.g., mental health, nutrition, cardiovascular health), period of data collection, country of origin or region, destination country or region, and summary of findings. In total, six research assistants extracted and collated data. Each paper was reviewed by one research assistant and verified by another for accuracy. The research assistants received four hours of training on scoping reviews and attended weekly meetings to discuss emerging findings.

Stage 5 involved collating, summarizing, and reporting the results. Given the vast number of articles included, we coded and summarised data based on areas of focus and thematically analysed the content. We also compared data across the coding segments. The purpose of the comparison was to identify relevant linkages (relationships, interactions, and consequences) across data. Numerical data are represented using descriptive statistics, frequencies, measures of central tendency, and measures of variability. As a scoping review, the purpose is to map out the existing evidence and summarise key study findings within different domains rather than evaluate the quality of individual studies to determine the risk of bias related to particular outcomes. Hence, in line with the review aim of providing an overview of the existing evidence base, a formal quality assessment of each study was not undertaken [25].

\section{Results}

\subsection{Characteristics of Included Studies}

A total of 187 studies were ultimately included in this scoping review (Figure 1). Supplementary Table S1 shows the key characteristics of the articles. The majority of the studies were quantitative $(n=159)$, with less representation in terms of qualitative $(\mathrm{n}=22)$ and mixed methods $(\mathrm{n}=6)$ research. The oldest year of publication was 1965, and the most recent article was published in 2019. The majority of studies either did not mention their sampling method $(n=133)$ or utilised a non-probabilistic method $(n=42)$. Data were collected from diverse sources including children, parents, medical records, national registries, and health care professionals. The top three modes of data collection were via multiple methods $(n=63)$, surveys and questionnaires $(n=38)$, and diagnostic or laboratory testing $(\mathrm{n}=34)$. Few studies reported the use of a theoretical framework $(\mathrm{n}=10)$; those that did, used frameworks based on health services for community living, cognitive theory, a social-ecological framework, a cultural competence framework, the health access model and household resources model, anthropological theory, the theory of segmental assimilation, narrative inquiry and ethnographic impressionism, and transgenerational trauma transference.

\subsection{Characteristics of Study Participants}

A broad range of children's ages was examined: under 1 year old $(n=25), 1-6$ years old $(n=30), 7-11$ years old $(n=22)$, and 12-18 years old $(n=133)$. Most studies either reported on migrants from multiple countries $(n=37)$ or generalised to migrants from Africa $(n=28)$. Others reported participants were from Somalia $(n=27)$, Ethiopia $(n=24)$, and sub-Saharan Africa $(n=13)$. European $(n=69)$ and African $(n=39)$ countries were the primary destinations, although a notable number of studies were conducted in Israel $(\mathrm{n}=26)$, the United States $(\mathrm{n}=22)$, and Australia $(\mathrm{n}=21)$.

\subsection{Identified Themes}

The studies included in this review report on 11 areas of health, namely, infectious diseases $(n=25)$, including parasitic infections $(n=17)$; nutrition $(n=40)$; mental health $(\mathrm{n}=28)$; birth outcomes and sexual/reproductive health $(\mathrm{n}=23)$; physical and developmental health $(n=19)$; oral health $(n=16)$; respiratory health $(n=9)$; preventative health 
$(\mathrm{n}=8)$; endocrine health $(\mathrm{n}=8)$; health care services $(\mathrm{n}=8)$; and haematological conditions $(\mathrm{n}=5)$.

\subsubsection{Infectious Diseases, Including Parasitic Infections}

Overall, 25 of the articles focus on infectious diseases [27-51]. The literature indicates high rates of human immunodeficiency virus (HIV) infection in AMC [45-50], and Germany [51]. Studies in Israel and Belgium found a high prevalence of mother-to-child HIV transmissions $[45,48]$. AMC living with HIV in the United States and the Netherlands are often diagnosed in the host country, with antiretroviral therapy started at an older age $[47,50]$ However, HIV-infected parents migrating to Sweden are unlikely to disclose their status to their children due to fear of double stigma [46].

Research shows hepatitis A and B are prevalent among AMC in Italy and Spain $[27,28]$. Similarly, problems with Chlamydia trachomatis, cholera, and varicella-zoster virus are evident in AMC in the United States and Algeria [29-31]. The presence of measles and rubella also affects the health of AMC in Cameroon and Cote d'Ivoire [32,33], as did Heliobacter pylori in Australia, although the latter was reduced by premigration antimalarial therapy [34-37]. Tinea capitis is a common infectious disease among AMC in New Zealand [38], Israel [39], Spain [40,41], and Australia [42]. Other scalp infections from Trichophyton violaceum and Trishophyton soudanense are also present in AMC living in Sweden and the United States $[43,44]$.

A total of 16 articles report on parasitology-seven report on malaria [52-58], four discuss helminth infections [35-37,59], and five focus on unspecified infections [60-64]. Intestinal parasites are common among AMC in the United States, Spain, and Australia [61-63,65]. Similarly, the infestation rate of head lice among AMC in Israel is high [64]. Among migrants to Spain, parasitic infections are most common in people originating from subSaharan and North Africa and are frequently associated with eosinophilia [62]. However, AMC in England have much lower helminth carriage rates than other migrant populations [59]. In Australia, helminth infections are also common but are not associated with reduced growth or with $H$. pylori infection [36], are not predicted by gastrointestinal symptoms and significantly elevated cytokines [37], and do not elevate urinary hepcidin [36]. The literature also shows imported childhood malaria is increasing among AMC in England [58] and Spain [52]. Similarly, Plasmodium falciparum infections are disproportionately high among AMC compared to populations in receiving countries such as Canada [53], the Democratic Republic of Congo [54], Australia [55], and Zambia [56]. Prevalence is thought to be partly connected to malnutrition [54], and receiving countries must be prepared to treat children for P. falciparum infections on arrival.

\subsubsection{Nutrition}

A total of 40 articles report on nutrition following arrival to the host country [65-104]. Concerning breastfeeding practices among mothers of AMC, scholars largely centre their attention on high-income settings such as Norway and Australia, or conversely on refugee camps in Africa. In developed countries, some authors report positive attitudes towards breastfeeding [66]; however, others note an interruption of breastfeeding at six months post-birth primarily due to insufficient milk supply [67], a decline in breastfeeding after arrival to the host country [68], and increased challenges to exclusive breastfeeding [69]. In contrast, refugees in Ghana improved their breastfeeding practices with increasing time in the receiving country [70]. Infant refugees to Algeria often experience excessive iodine intake [71] and are constantly underweight [72].

Evidence on dietary choices and feeding behaviours of AMC vary across settings. In Algeria, Italy, and Spain, several authors report lower quality diets in AMC soon after their arrival [73,74]. For instance, some immigrants to Italy are less likely to have breakfast compared to Italians [75]. Conversely, AMC in Norway appear to align with Norwegian dietary recommendations [76], and AMC in the United States make dietary choices that are highly influenced by their culture [77]. Factors associated with child hunger and 
food insecurity include poor English proficiency and shorter length of stay in the host country $[78,79]$.

Issues related to obesity and overweight have appeared upon resettlement of AMC in host countries including the United States, the Netherlands, and Australia [80-83]. Some authors attribute these health issues to cigarette smoking [84] and changes to traditional lifestyle [81]. Similarly, vitamin D deficiency or insufficiency is a frequent concern for AMC living in Australia and Germany [85-87]. In contrast, AMC with body mass indexes (BMIs) indicating underweight problems are also reported in the literature, specifically in Canada [88], Saudi Arabia [89], Zaire [90], Israel [91], Kenya [92], Scotland [60], the United States [65], and in migrants to Kenya, Ethiopia, Uganda, and Algeria [93]. Some authors credit weight issues to non-consumption of milk, low literacy of fathers, and having no immunisation card [94].

To resolve nutrition-related concerns of AMC, host countries such as Australia have designed, implemented, and evaluated culturally competent obesity-prevention programs through community-partnered participatory approaches [95]. Likewise, lipid-based nutrient supplement programs have been implemented in Algeria [96], nutrient-dense fortified spread programs in the United States [97], and maize meal fortification in Zambia [98]. However, despite an increase of interventions, acute malnutrition remained prevalent in Somalia [99], no significant change in haemoglobin with micronutrient powder was observed in Kenya [100], and malnutrition rates for migrants to Zaire persisted [101].

\subsubsection{Mental Health}

In total, 25 of the articles focus on the mental health of AMC [105-132]. Post-traumatic stress disorder (PTSD) is linked to having experienced traumatic events such as war and violence [105-107]. Girls are more likely to develop this problem [107]. Other mental health issues among AMC in Israel include suicide ideation and alcohol abuse [108,109], anxiety, and depression $[109,110]$. Similarly, in Uganda, exposure to violence is associated with higher symptoms of depression among AMC [111], and the psychosocial well-being of AMC is impacted by the potential influx of refugees [112]. However, in Norway, AMC experience less stressful events compared to migrants from Asia [113], and in Australia, the social-emotional well-being of AMC improves over time, with children who had four or more protective factors at low risk of poor social-emotional well-being [114].

Many authors report issues of discrimination, racism, and emotional breakdowns experienced by AMC in the Netherlands [115], Canada [116], and the United Kingdom [117]. Likewise, behavioural problems are seen to arise with ambivalent acculturation patterns $[105,118]$ and negative perspectives on mental illness in AMC [119]. In Canada and Israel, some authors identify personal characteristics, interpersonal relationships, environmental characteristics, and the family as factors that influence AMC's identity and sense of belonging [120,121]. In Italy, AMC who integrated into the national culture show higher self-esteem, life satisfaction, and socio-cultural competence relative to their non-integrated counterparts [122]. Despite the mental health concerns among AMC, contact with mental health services in destination countries such as the UK appears limited [123].

Three articles discuss child trafficking among AMC [124-126]. Iyakaremye and Mukagatare [124] note that child trafficking is facilitated by the poor standard of living in the refugee camp, convoluted camp layout, and inadequate security system, which negatively impacts girls' reproductive health, social integration, and mental health. As a result, researchers in Rwanda found that stigma negatively impacted girls' access to health services [125]. Finally, Warria [126] concludes that cultural-responsive care becomes a highly important practice method for a child welfare practitioner when engaging with transnational trafficked children from diverse sociocultural, linguistic, economic, and ethnic backgrounds. 


\subsubsection{Birth Outcomes and Reproductive and Sexual Health}

Overall, 23 of the articles included in this review examine birth outcomes, with less focus on the reproductive and sexual health of AMC [133-155]. A higher prevalence of preterm births is seen in Portugal and Belgium [133-135], while infant mortality is prevalent in places including Tanzania [136], Canada [137], Italy [138], and South Africa [139]. Similarly, perinatal mortality in African migrant women is high in Sweden [140] and Belgium [135]. Birthweights of AMC vary across studies; for instance, some authors report low birthweights or high risk for low birthweights in Belgium, Israel, and Spain [141-144], whereas others note higher birth weights among AMC in these same countries and less likelihood of being born preterm or with low birth weight [145-147]. In the United States, researchers found new-borns to Somali immigrants are at increased risk for prolonged hospitalisation, lower 5-min Apgar scores, assisted ventilation, and meconium aspiration [148]. In contrast, other authors report no relationship between preterm birth and low birth weights [149].

In terms of sexual and reproductive health, in Ethiopia, AMC reported multiple sources of sexual and reproductive health information including parents, peers, and religious leaders [150]. Migrants to Portugal reported difficulties talking about sex with parents, the tendency to begin sexual life early, and the infrequent use of condoms [151]. On the other hand, some authors report no evidence linking female circumcision to perinatal death in migrants to Sweden [152] and confirm the significance of non-therapeutic male circumcision in migrants to Spain [153]. In addition, the literature shows Somali girls accept but are less likely to complete the human papillomavirus (HPV) vaccine series [154], and AMC in the United States who live in minority diversity neighbourhoods saw protective effects on infant health [155].

\subsubsection{Physical and Developmental Health}

A total of 19 articles discuss physical and developmental health [61,95,119,156-171] and shed light on AMC's growth and development. For example, AMC in Israel, the United States, and France are more likely to fail tests assessing fine-motor skill, linguistic, and socio-emotional domains [156], and to have poor growth [61] and a low BMI [61]. In addition, AMC in the USA represent the majority of profound biotinidase deficiency (BTD) cases; however, none had partial BTD [157]. Conversely, AMC in Scotland grow to taller heights than Asian migrants [158].

Ethiopian child migrants to Israel have lower rates of pervasive developmental disorder (PDD), compared to immigrants from other countries and native Israeli children [159]. AMC in Sweden and the United States have a high prevalence of autism spectrum disorder (ASD) [160-162]. In other receiving countries, some authors report familial challenges to the acceptance and understanding of child migrants' autism, which include cultural attitudes towards mental illness, behaviour, and disability, in addition to a lack of vocabulary to describe the disorder [163]. Additionally, AMC in Australia report a negative perspective on mental illness within the community, with $85 \%$ reporting bad perceptions of ASD [119].

AMC in the Netherlands are significantly more likely to watch television for two or more hours per day, compared to native Dutch children [164]. East African migrants report a desire to be physically active, but migrants to both the United States and Australia face challenges to physical inactivity, including social, environmental, and cultural barriers $[165,166]$. On the contrary, Somali child migrants to the United States are more likely to play soccer than other black peers; the girls have lower activity levels compared to black and white peers, but no differences are noted for boys [167].

Non-communicable diseases such as neonatal jaundice [168] sickle-cell disease [169], and Kawasaki disease [170] are common in AMC in Norway, Canada, and the United States.

\subsubsection{Oral Health}

In total, 17 of the included studies focus on oral health [61,65,172-185], with many examining the oral health of AMC in Israel. While some report an issue with missing 
teeth $[172,173]$, others note low levels of caries, especially if the AMC has recently arrived $[65,174-177]$. Additionally, parents of AMC report less frequent daily toothbrushing and dentist visits, when compared to their Israeli counterparts [178]. Few or no dental visits are common among AMC in the United States [184] and Canada [179]. Dental abnormalities, poor oral hygiene, and prevalence of caries are also common among AMC $[61,181]$ Barriers to the prevention of early childhood caries are associated with home-based prevention, early detection, and health care access [182].

\subsubsection{Respiratory Health}

Nine articles discuss respiratory health [61,186-193]. AMC in Israel, the United States, and the Netherlands report issues with asthma; however, most show a lower prevalence and better health-related quality of life, compared to local children [186-188]. Authors report issues with tuberculosis (TB) among AMC in the United States, Sweden, Israel, and Australia [61,189-193]. The appearance of this disease has been linked to lower height-forage $\mathrm{z}$ scores [61]. AMC are typically diagnosed within three years upon arriving in the host country [190], and asthma in young AMC (0-4 years) is frequently detected [190].

\subsubsection{Preventative Health}

Nine studies report on preventative health in AMC [30,154,156,194-199]. Paxton et al. [194] note that $97 \%$ of AMC have incomplete or uncertain immunisation status, while other authors suggest serological screening to update the immunisation status of AMC in Italy [195]. In Malawi, evidence shows AMC sometimes lack their second dose of measles vaccine [196]. Similarly, in the United States, girls generally accept initiating the HPV vaccine but less likely to complete the series [154]. In contrast, AMC in Israel and the United States have complete vaccination schedules [154], and their antibody levels against many viruses are similar or higher than non-immigrants [197]. Regarding cardiovascular health, Colombatti et al. [198] declare a need for parental education in the native language on stroke risk and prevention of sickle cell disease (SCD) to increase compliance. Likewise, two studies point out the need for updated policies, education, and an increase of vaccine uptake or routine testing for antibodies [30,199].

\subsubsection{Endocrine Health}

Of the eight articles that report on endocrine health, four focus on type 1 diabetes (T1D) [200-203] and four on thyroid pathologies [71,204,205]. The literature shows T1D is often present in AMC in host countries such as Italy, the Netherlands, and Sweden [200-202], and that this issue often develops after arrival in host countries [200]. Further, AMC have a higher risk of T1D with increasing time their mother spent in the receiving nation [201]. In contrast, AMC in Finland have a similar prevalence of T1D as Finnish children [203].

On the other hand, researchers report excessive iodine intake in infants in Algeria [204] and children suffering from endemic goitre likely caused by excessive iodine intake [205]; a relationship between excessive iodine intake with thyroid dysfunction and poorer developmental status is reported [204]. Conversely, Ethiopian immigrants to Israel experience a high prevalence of goitre with a low frequency of hypothyroidism, which may be attributed to food goitrogens and iodine deficiency prevailing in Ethiopia [206].

\subsubsection{Health care Services}

Eight of the studies included in this review analyse health care services [119,123,207-212]. AMC in the UK indicate not having contact with health care services [123]; AMC in Israel adopt Western practices and go to the clinic for medical treatment, but if this does not prove satisfactory, they seek out solutions according to familiar patterns from their country of origin for medical, social, or emotional problems [207]. Similarly, AMC caregivers in South Africa report dissatisfaction with health care services [208], and AMC in Spain report a sense of pointlessness in seeking out health care services [209]. On the contrary, AMC in Australia have highly accessible primary care $[119,210]$, and the major barriers to access 
are the availability of interpreters and lack of information [211]. For migrants to Uganda, proximity, maternal perceived severity of illness, financial resources, and permission from the father determine treatment access [212].

\subsubsection{Haematological Conditions}

Five of the included articles focus on haematology concerns [158,169,213-215]. For instance, Plotinsky et al. (2008) [213] note that blood lead levels (BLLs) of refugees are significantly higher than among non-refugee children. Similarly, Goel et al. (2009) [158] suggest nutritional iron deficiency remains the most common cause of anaemia in African immigrants. AMC in Canada represent 25\% of all patients with SCD born abroad [214]: some authors suggest that early recognition and intervention may reduce this problem [215]. In addition, bilingual migrant children to Italy with SCD display a rate of cognitive impairment similar to their monolingual counterparts but have a more pronounced and precocious onset of language difficulties [169].

\section{Discussion}

In providing a comprehensive overview of the empirical evidence on AMC, this scoping review systematically synthesises the breadth, range, and nature of the evidence on the health of African migrant children across the globe. It is crucial to scope the literature on African migrant children to map the research in the field and gain more insight into the gaps in the literature. Due to our large time range (1967-2019), it is important to note that changes in policies over time may affect migrants. Our findings indicate that scholars have largely focused on the nutritional, mental, and infectious diseases of migrant children from Sudan, Ethiopia, and Somalia who are living in European countries such as Spain and Italy. Results from our review indicate most included articles utilise a quantitative approach, with only a few incorporating a theoretical lens to guide research. More qualitative and participatory action research studies are needed because these approaches are essential to amplify the voices of African migrant children further through research processes. While many of the studies included children as data sources, these were overwhelmingly quantitative. Only 10 studies were qualitative and gathered data from migrant and refugee children from countries in sub-Saharan Africa [112,116,120,124,125,129,132,150,166,207]. The rest of the qualitative studies gathered data about children from parents or service provider participants. In addition, there is a need to focus on children as bearers of rights under the United Nations Convention on the Rights of the Child. For example, children have the right to have basic needs met and the right to access the necessities of a good life. Based on these discoveries, we make recommendations for practice, public health policy, and future research.

Evidence on African immigrants and refugees in a mental health care setting shows that, by actively involving study participants, researchers are able to ensure meaningful and culturally appropriate scholarly work [216]. Similarly, Murray et al. [217] found participant engagement in the research process positively influenced physical activity behaviour in East African communities in the United States; these engagements undoubtedly tap into communal agency, knowledge, and sense of belonging. Worth noting also is that many articles included in this review lack a theoretical framework. We, similar to others, argue that theory can permeate the entire research process, thus allowing intellectuals to enhance the plan, design, and evaluation of their investigations [218-220]. We suggest a theorydriven approach can add value to future research on AMC, including intervention work.

In 2017, of the 36 million African transnational migrants, 19 million live within the African continent, and the rest migrated transcontinentally; African migrants younger than 24 years of age made up $38 \%$ of the total number of migrants, over six million were migrant children, and about seven million were internally displaced [221]. Data from 2019 show African migrants and refugees continue to move within the African continent, with Egypt, Morocco, Algeria, and Sudan among the top sending countries and Cote d'Ivoire and South Africa the leading host countries [1]. Even though European countries continue to be 
the top destinations for African migrants who go pancontinental, other countries, such as Canada, have recently reported an arrival increase of African nationals [222]. Thus, further research is needed in countries that host large numbers of AMC, such as South Africa and Canada. Again, contrary to the long-publicised wave of African migrants moving away from the continent in the media, further research on African migrants within the continent itself is also needed because, as observed in this review, a relatively higher proportion of African migrants continue to be hosted in other African destination countries. In West Africa, for example, there is considerably more interaction among countries within the subregion due to the Economic Community of West African States (ECOWAS) free movement of people and goods protocol. Quite admittedly, however, destination countries outside the African continent are more unfriendly and unfamiliar for many migrants compared to those within Africa and, therefore, the health-related outcomes for many AMC outside the African continent may be graver than for those within the region but outside their countries of origin. Finally, the current global COVID-19 outbreak will undoubtedly have impacts on the health of AMC. Future studies are needed to understand these impacts and implications.

The results from this scoping review underline major issues that could be related to the health beliefs and cultural practices of migrant families that impact child health. Many scholars report the poor communication between AMC and their parents about sex, a lack of importance given to their oral health and dietary choices, and inadequacy of breastfeeding practices. These findings are consistent with other research on African immigrant populations, in which scientists have found traditional beliefs of African immigrant women interfere with exclusive breastfeeding during the first six months of a child's development [223]. Likewise, African immigrants in college culturally perceive American food as unhealthy, yet they become acculturated to it [224]. In contrast, Cooper Brathwaite and Lemonde [225] discovered that immigrants from Ghana and Nigeria rely on their health beliefs and cultural practices in the prevention of type 2 diabetes, and also preserve their culture through their food choices.

The articles included in this scoping review report on the experiences of AMC and the health care system. Studies show barriers across a range of destination country contexts include language barriers and a lack of translation services [226], long wait times and dissatisfaction with care $[11,208]$, and financial costs, especially concerning non-basic health care [11]. As explained above, migration and settlement journeys can impact health and access to care in new countries. Lack of status or proper documentation is an acute barrier to access. For example, even though children under six years of age in South Africa are entitled to health care regardless of status, they often do not have access to the necessary paperwork [227].

Our results echo other research with immigrant populations, in which discrimination, racism, fear, cultural diversities, and the lack of effective communication with health care providers often lead to dissatisfaction towards health care services [228-230]. These barriers to African immigrant and refugee children's access to health care have demonstrable impacts on child health. Data from the United States show race and immigration status impact youth health in intersectional ways; specifically, many Somali immigrants and refugee children are not meeting Healthy People 2020 Objectives, scoring particularly low in mental health and healthy weight goals [231]. There is an urgent need for culturally trained practitioners, especially in areas high in migrants. Cultural competency interventions have been shown to improve a series of outcomes such as access to health care and patient outcomes [232]. Hence, we suggest the implementation of these interventions could help to improve the satisfaction of AMC with the health care systems in host countries by increasing awareness of cultural norms among health care providers.

Finally, childhood tuberculosis and latent tuberculosis are important topics to consider in African Immigrant children's health. However, this scoping review found little data concerning either diagnosis and treatment or prevention among this population. More studies are needed to fill this gap. 


\section{Conclusions}

Our findings suggest a need to investigate other least researched health concerns of AMC. The World Health Organization [233] reported that, in 2015, pneumonia killed more than 900,000 African children under 5 years old, and about a quarter of all African adults had suffered physical violence during their childhood. Similarly, AMC to Europe are repeatedly exposed to maltreatment during their migration journey [234]. Child maltreatment can include physical, emotional, or sexual abuse, neglect, negligence, or exploitation. In this regard, we suggest the creation of policies aimed at providing health assessments for AMC to identify individualised health care needs as soon as possible. Health examinations should emphasise the newly arrived AMC and also involve continuous care. This is important because evidence shows recent immigrants present a healthy immigrant effect [235]. As UN Member States aim to achieve universal health coverage (UHC) by 2030, which is a critical part of the Sustainable Development Goals, it is imperative to optimise full access to the range of essential, quality health services, from health promotion to preventive, curative, and rehabilitative care.

\section{Limitations}

This scoping review provides a comprehensive overview of the empirical evidence on AMC; however, it has its limitations. Due to the nature of the methodology, details of the included studies are not discussed in this article, nor is a formal critical appraisal or bias assessment available. Although we conducted a broad search, some articles might have been missed if they were published in other languages, used alternative keywords, were published in African journals not indexed in the databases searched, cultural sensitivity in service provision, climatic adaptation, and clothing support. Additionally, there is a limitation in considering only the experiences of sub-Saharan migrants and excluding those from North Africa. However, we make this distinction due to differences in culture between countries in North Africa and other regions.

Supplementary Materials: The following are available online at https:/ /www.mdpi.com/article/10 .3390/ijerph18073514/s1, Table S1: Key Findings.

Author Contributions: Conceptualization, B.S., C.F., S.O.K., M.A.-A., P.O.-I., H.G., C.M.N. and S.R.; methodology, B.S.; software, B.S.; validation, H.F.S.; formal analysis, B.S., H.F.-S., and A.B.; investigation, B.S., H.F.-S., C.F., C.E., L.S., M.T., and M.A.-A.; resources, B.S.; data curation, B.S.; writing — original draft preparation, B.S., H.F.-S. and A.B.; writing—review and editing, C.F., C.E., L.S., M.T., A.B., S.O.K., M.A.-A., P.O.-I., H.G., K.A., C.M.N. and S.R.; visualization, B.S.; supervision, B.S. and H.F.-S.; project administration, B.S.; funding acquisition, B.S., C.F., L.S., S.O.K., M.A.-A., P.O.-I., H.G., C.M.N. and S.R. All authors have read and agreed to the published version of the manuscript.

Funding: This research was funded by the Worldwide Universities Network Research Development Fund and the Social Sciences and Humanities Research Council of Canada Partnership Development Grant, grant number \# 890-2018-0096.

Acknowledgments: We acknowledge the work of several research assistants who worked on article selection for this project: Oluwakemi Amodu, Oghenevwarho Ojakovo, Alleson Mason, Siciida Ibrahim, Folakemi Ojo, and Iyanu Soyege. We also acknowledge the support of the following trainees with respect to data extraction and data analysis: Afrina Tasneem, Carolyne Dos Santos, Nicole Macleod, Beatriz Parreira Santos, and Olabisi Olagunju.

Conflicts of Interest: The authors declare no conflict of interest. The funders had no role in the design of the study; in the collection, analyses, or interpretation of data; in the writing of the manuscript; or in the decision to publish the results.

\section{References}

1. International Organization for Migration. World Migration Report 2020; United Nations: Geneva, Switzerland, 2019.

2. McDonald, J.T.; Kennedy, S. Insights into the 'healthy immigrant effect': Health status and health service use of immigrants to Canada. Soc. Sci. Med. 2004, 59, 1613-1627. [CrossRef] [PubMed] 
3. Kennedy, S.; Kidd, M.P.; McDonald, J.T.; Biddle, N. The healthy immigrant effect: Patterns and evidence from four countries. J. Int. Migr. Integr. 2015, 16, 317-332. [CrossRef]

4. Lu, C.; $\mathrm{Ng}$, E. Healthy immigrant effect by immigrant category in Canada. Health Rep. 2009, 30, 3-11. [CrossRef]

5. Harker, K. Immigrant generation, assimilation, and adolescent psychological well-being. Soc. Forces 2001, 79, 969-1004. [CrossRef]

6. Stevens, G.W.; Walsh, S.D.; Huijts, T.; Maes, M.; Madsen, K.R.; Cavallo, F.; Molcho, M. An internationally comparative study of immigration and adolescent emotional and behavioral problems: Effects of generation and gender. J. Adolesc. Health 2015, 57, 587-594. [CrossRef]

7. Anderson, K.K.; Cheng, J.; Susser, E.; McKenzie, K.J.; Kurdyak, P. Incidence of psychotic disorders among first-generation immigrants and refugees in Ontario. Can. Med. Assoc. J. 2015, 187, E279-E286. [CrossRef]

8. Omenka, O.I.; Watson, D.P.; Hendrie, H.C. Understanding the healthcare experiences and needs of African immigrants in the United States: A scoping review. BMC Public Health 2020, 20, 27. [CrossRef]

9. Venters, H.; Gany, F. African immigrant health. J. Immigr. Minor. Health 2011, 13, 333-344. [CrossRef]

10. Ahmed, S.; Rasmussen, A. Changes in social status and postmigration mental health among West African immigrants. Am. J. Orthopsychiatry 2020, 90, 171-180. [CrossRef]

11. Woodgate, R.L.; Busolo, D.S.; Crockett, M.; Dean, R.A.; Armaladas, M.R.; Plourde, P.J. A qualitative study on African immigrant and refugee families' experiences of accessing primary health care services in Manitoba, Canada: It's not easy! Int. J. Equity Health 2017, 16, 5-17. [CrossRef]

12. Migration Policy Institute. Sub-Saharan African Immigrants in the United States; Migration Policy Institute: Washington, DC, USA, 2019.

13. Salami, B.; Yaskina, M.; Hegadoren, K.; Diaz, E.; Meherali, S.; Rammohan, A.; Ben-Shlomo, Y. Migration and social determinants of mental health: Results from the Canadian Health Measures Survey. Can. J. Public Health 2017, 108, 362-367. [CrossRef] [PubMed]

14. Salami, B.; Hirani, S.; Meherali, S.; Amodu, O.; Chambers, T. Parenting practices of African immigrants in destination countries: A qualitative research synthesis. J. Pediatr. Nurs. 2017, 36, 30-40. [CrossRef] [PubMed]

15. Hamilton, H.A.; Noh, S.; Adlaf, E.M. Adolescent risk behaviours and psychological distress across immigrant generations. Can. J. Public Health 2009, 100, 221-225. [CrossRef]

16. Kwak, K. An evaluation of the healthy immigrant effect with adolescents in Canada: Examinations of gender and length of residence. Soc. Sci. Med. 2016, 157, 87-95. [CrossRef]

17. Bronstein, I.; Montgomery, P. Psychological distress in refugee children: A systematic review. Clin. Child Fam. Psychol. Rev. 2011, 14, 44-56. [CrossRef]

18. Crowley, C. The mental health needs of refugee children: A review of literature and implications for nurse practitioners. J. Am. Acad. Nurse Pract. 2009, 21, 322-331. [CrossRef] [PubMed]

19. Lustig, S.L.; Kia-Keating, M.; Knight, W.G.; Geltman, P.; Ellis, H.; Kinzie, J.D.; Keane, T.; Saxe, G.N. Review of child and adolescent refugee mental health. J. Am. Acad. Child Adolesc. Psychiatry 2004, 43, 24-36. [CrossRef] [PubMed]

20. Pieloch, K.A.; McCullough, M.B.; Marks, A.K. Resilience of children with refugee statuses: A research review. Can. Psychol./Psychol. Can. 2016, 57, 330-339. [CrossRef]

21. Baauw, A.; Kist-van Holthe, J.; Slattery, B.; Heymans, M.; Chinapaw, M.; van Goudoever, H. Health needs of refugee children identified on arrival in reception countries: A systematic review and meta-analysis. BMJ Paediatr. Open 2019, 3, e000516. [CrossRef]

22. Reza, M.; Amin, M.S.; Sgro, A.; Abdelaziz, A.; Ito, D.; Main, P.; Azarpazhooh, A. Oral health status of immigrant and refugee children in North America: A scoping review. J. Can. Dent. Assoc. 2016, 82, 1488-2159.

23. Peters, M.D.; Godfrey, C.M.; Khalil, H.; McInerney, P.; Parker, D.; Soares, C.B. Guidance for conducting systematic scoping reviews. Int. J. Evid. Based Healthc. 2015, 13, 141-146. [CrossRef]

24. Munn, Z.; Peters, M.D.J.; Stern, C.; Tufanaru, C.; McArthur, A.; Aromataris, E. Systematic review or scoping review? Guidance for authors when choosing between a systematic or scoping review approach. BMC Med. Res. Methodol. 2018, 18, 143. [CrossRef]

25. Arksey, H.; O’Malley, L. Scoping studies: Towards a methodological framework. Int. J. Soc. Res. Methodol. 2005, 8, 19-32. [CrossRef]

26. Tricco, A.C.; Lillie, E.; Zarin, W.; O’Brien, K.K.; Colquhoun, H.; Levac, D.; Moher, D.; Peters, M.D.J.; Horsley, T.; Weeks, L.; et al. PRISMA extension for scoping reviews (PRISMA-ScR): Checklist and explanation. Ann. Intern. Med. 2018, 169, 467-473. [CrossRef]

27. Faustini, A.; Franco, E.; Saitto, C.; Cauletti, M.; Zaratti, L.; Papini, P.; Ahmed, A.; Zampieri, F.; Lerussi, A.; Panna, A.; et al. Hepatitis A, B, C and D in a community in Italy of immigrants from NE Africa. J. Public Health 1994, 16, 71-78. [CrossRef]

28. Huerga, H.; López-Vélez, R. Infectious diseases in sub-Saharan African immigrant children in Madrid, Spain. Pediatr. Infect. Dis. J. 2002, 21, 830-834. [CrossRef] [PubMed]

29. Javaloy, J.; Ferrer, C.; Vidal, M.T.; Alió, J.L. Follicular conjunctivitis caused by chlamydia trachomatis in an infant Saharan population: Molecular and clinical diagnosis. Br. J. Ophthalmol. 2003, 87, 142-146. [CrossRef] [PubMed]

30. Nysse, L.J.; Pinsky, N.A.; Bratberg, J.P.; Babar-Weber, A.Y.; Samuel, T.T.; Krych, E.H.; Ziegler, A.; Jimale, M.A.; Vierkant, R.A.; Jacobson, R.M.; et al. Seroprevalence of antibody to varicella among Somali refugees. Mayo Clin. Proc. 2007, 82, 175-180. [CrossRef] 
31. Swerdlow, D.L.; Malenga, G.; Begkoyian, G.; Nyangulu, D.; Toole, M.; Waldma, R.J.; Puhr, D.N.; Tauxe, R.V. Epidemic cholera among refugees in Malawi, Africa: Treatment and transmission. Epidemiol. Infect. 1997, 118, 207-214. [CrossRef]

32. Kouadio, I.K.; Koffi, A.K.; Attoh-Toure, H.; Kamigaki, T.; Oshitani, H. Outbreak of measles and rubella in refugee transit camps. Epidemiol. Infect. 2009, 137, 1593-1601. [CrossRef]

33. Ndombo, P.K.; Ndze, V.N.; Mbarga, F.D.; Anderson, R.; Acho, A.; Ebua Chia, J.; Njamnshi, A.K.; Rota, P.A.; Waku-Kouomou, D. Molecular tilizationion of measles virus strains among refugees from Central African Republic in Cameroon in 2014. Epidemiol. Infect. 2018, 146, 319-323. [CrossRef]

34. Cherian, S.; Forbes, D.A.; Cook, A.G.; Sanfilippo, F.M.; Kemna, E.H.J.M.; Swinkels, D.W.; Burgner, D.P. An insight into the relationships between hepcidin, anemia, infections and inflammatory cytokines in pediatric refugees: A cross-sectional study. PLOS ONE 2008, 3, e4030. [CrossRef]

35. Cherian, S.; Forbes, D.; Sanfilippo, F.; Cook, A.; Burgner, D. The epidemiology of Helicobacter pylori infection in African refugee children resettled in Australia. Med. J. Aust. 2008, 189, 438-441. [CrossRef] [PubMed]

36. Cherian, S.; Forbes, D.; Sanfilippo, F.; Cook, A.; Burgner, D. Helicobacter pylori, helminth infections and growth: A cross-sectional study in a high prevalence population. Acta Paediatr. 2009, 98, 860-864. [CrossRef] [PubMed]

37. Cherian, S.; Burgner, D.P.; Cook, A.G.; Sanfilippo, F.M.; Forbes, D.A. Associations between helicobacter pylori infection, co-morbid infections, gastrointestinal symptoms, and circulating cytokines in African children. Helicobacter 2010, 15, 88-97. [CrossRef]

38. Lamb, S.R.; Rademaker, M. Tinea due to trichophyton violaceum and trichophyton soudanense in Hamilton, New Zealand. Australas. J. Dermatol. 2001, 42, 260-263. [CrossRef]

39. Mashiah, J.; Kutz, A.; Ami, R.B.; Savion, M.; Goldberg, I.; Or, T.G.; Zidan, O.; Sprecher, E.; Harel, A. Tinea capitis outbreak among paediatric refugee population, an evolving healthcare challenge. Mycoses 2016, 59, 553-557. [CrossRef] [PubMed]

40. Cuetara, M.S.; Palacio, A.; Pereiro, M.; Amor, E.; Alvarez, C.; Noriega, A.R. Prevalence of undetected tinea capitis in a school survey in Spain. Mycoses 1997, 40, 131-137. [CrossRef]

41. Cuetara, M.S.; Palacio, A.D.; Pereiro, M.; Noriega, A.R. Prevalence of undetected tinea capitis in a prospective school survey in Madrid: Emergence of new causative fungi. Br. J. Dermatol. 1998, 138, 658-660. [CrossRef] [PubMed]

42. McPherson, M.E.; Woodgyer, A.J.; Simpson, K.; Chong, A.H. High prevalence of tinea capitis in newly arrived migrants at an English-language school, Melbourne, 2005. Med. J. Aust. 2008, 189, 13-16. [CrossRef]

43. Grigoryan, K.V.; Tollefson, M.M.; Olson, M.A.; Newman, C.C. Pediatric tinea capitis caused by Trichophyton violaceum and Trichophyton soudanense in Rochester, Minnesota, United States. Int. J. Dermatol. 2018, 58, 912-915. [CrossRef]

44. Hällgren, J.; Petrini, B.; Wahlgren, C. Increasing tinea capitis prevalence in Stockholm reflects immigration. Med. Mycol. 2004, 42, 505-509. [CrossRef] [PubMed]

45. Agmon-Levin, N.; Elbirt, D.; Asher, I.; Torten, D.; Cohen, Y.; Gradestein, S.; Werner, B.; Turner, D.; Chowers, M.; Gotteseman, G.; et al. Prevention of human immunodeficiency virus mother-to-child transmission in Israel. Int. J. STD AIDS 2009, 20, 473-476. [CrossRef]

46. Asander, A.S.; Björkman, A.; Belfrage, E.; Faxelid, E. HIV-infected African parents living in Stockholm, Sweden: Disclosure and planning for their children's future. Health Soc. Work 2009, 34, 107-115. [CrossRef] [PubMed]

47. Cohen, S.; Bilsen, W.P.; van Smit, C.; Fraaij, P.L.; Warris, A.; Kuijpers, T.W.; Geelen, S.; Worlfs, T.; Scherpbrier, H.; van Rossum, A.; et al. Country of birth does not influence long-term clinical, virologic, and immunological outcome of HIV-infected children living in the Netherlands: A cohort study comparing children born in the Netherlands with children born in Sub-Saharan Africa. J. Acquir. Immune Defic. Syndr. 2015, 68, 178-185. [CrossRef] [PubMed]

48. Feiterna-Sperling, C.; Königs, C.; Notheis, G.; Buchholz, B.; Krüger, R.; Weizsäcker, K.; Eberle, J.; Hanhoff, N.; Gartner, B.; Heider, H.; et al. High seroprevalence of antibodies against Kaposi's sarcoma-associated herpesvirus (KSHV) among HIV-1infected children and adolescents in a non-ethnic population. Med. Microbiol. Immunol. 2016, 205, 425-434. [CrossRef]

49. Irova, T.; Burtonboy, G.; Ninane, J. HIV infection in children born before and after immigration to Belgium. J. Travel Med. 1995, 2, 169-173. [CrossRef]

50. Nesheim, S.; Linley, L.; Gray, K.; Zhang, T.; Shi, J.; Lampe, M.; FitzHarris, L.F. Country of birth of children with diagnosed HIV infection in the United States, 2008-2014. J. Acquir. Immune Defic. Syndr. 2018, 77, 23-30. [CrossRef]

51. Neubert, J.; Michalsky, N.; Laws, H.J.; Borkhardt, A.; Jensen, B.; Lübke, N. HIV-1 Subtype diversity and prevalence of primary drug resistance in a single-center pediatric cohort in Germany. Intervirology 2017, 59, 301-306. [CrossRef]

52. Arnáez, J.; Roa, M.A.; Albert, L.; Cogollos, R.; Rubio, J.M.; Villares, R.; Alarabe, A.; Cervera, A.; Lopez-Velez, R. Imported malaria in children: A comparative study between recent immigrants and immigrant travelers (VFRs). J. Travel Med. 2010, 17, $221-227$. [CrossRef] [PubMed]

53. Asch, A.J. Malaria at the Hospital for Sick Children, Toronto. CMAJ Can. Med. Assoc. J. 1976, 115, 405-406.

54. Wolday, D.; Kibreab, T.; Bukenya, D.; Kodes, R. Sensitivity of Plasmodium falciparum in vivo to chloroquine and pyrimethaminesulfadoxine in Rwandan patients in a refugee camp in Zaire. Trans. R. Soc. Trop. Med. Hyg. 1995, 89, 654-656. [CrossRef]

55. Cherian, S.; Burgner, D. Selective ambulatory management of plasmodium falciparum malaria in paediatric refugees. Arch. Dis. Child. 2007, 92, 983-986. [CrossRef]

56. Depoortere, E.; Guthmann, J.; Sipilanyambe, N.; Nkandu, E.; Fermon, F.; Balkan, S.; Legros, D. Adherence to the combination of sulphadoxine-pyrimethamine and artesunate in the Maheba refugee settlement, Zambia. Trop. Med. Int. Health 2004, 9, 62-67. [CrossRef] [PubMed] 
57. Lavoie, P.M.; Carceller, A.; Robert, M.; Lebel, M.H.; Moore, D.L.; Rashed, S. Malaria in immigrant and traveler children: Clinical presentation and risk factors for complications. J. Pediatr. Infect. Dis. 2006, 1, 29-37. [CrossRef]

58. Williams, J.P.; Chitre, M.; Sharland, M. Increasing Plasmodium falciparum malaria in southwest London: A 25 year observational study. Arch. Dis. Child. 2002, 86, 428-430. [CrossRef] [PubMed]

59. Thompson, R.G.; Hutchison, J.G.; Johnston, N.M. Survey of intestinal pathogens from immigrant children. BMJ 1972, 1, 591-594. [CrossRef]

60. Goel, K.M.; Logan, R.W.; House, F.; Connell, M.D.; Strevens, E.; Watson, W.H.; Bulloch, C.B. The prevalence of haemoglobinopathies, nutritional iron and folate deficiencies in native and immigrant children in Glasgow. Health Bull. 1978, 36, 176-183.

61. Geltman, P.L.; Radin, M.; Zhang, Z.; Cochran, J.; Meyers, A.F. Growth status and related medical conditions among refugee children in Massachusetts, 1995-1998. Am. J. Public Health 2001, 91, 1800-1805. [CrossRef]

62. Belhassen-García, M.; Pardo-Lledias, J.; Pérez del Villar, L.; Muro, A.; Velasco-Tirado, V.; Muñoz Bellido, J.L.; Vicente, B.; Blazquez de Castro, A.; Cordero-Sanchez, M. Should parasitic disease be investigated in immigrant children with relative eosinophilia from tropical and sub-tropical regions? Paediatr. Int. Child Health 2017, 37, 42-45. [CrossRef] [PubMed]

63. Rice, J.E.; Skull, S.A.; Pearce, C.; Mulholland, N.; Davie, G.; Carapetis, J.R. Screening for intestinal parasites in recently arrived children from east Africa. J. Paediatr. Child Health 2003, 39, 456-459. [CrossRef] [PubMed]

64. Mumcuoglu, K.Y.; Miller, J.; Manor, O.; Ben-Yshai, F.; Klaus, S. The prevalence of ectoparasites in Ethiopian immigrants. Isr. J. Med. Sci. 1993, 29, 371-373. [CrossRef] [PubMed]

65. Shah, A.; Suchdev, P.; Mitchell, T.; Shetty, S.; Warner, C.; Oladele, A.; Reines, S. Nutritional status of refugee children entering DeKalb County, Georgia. J. Immigr. Minor. Health 2014, 16, 959-967. [CrossRef]

66. Wandel, M.; Terragni, L.; Nguyen, C.; Lyngstad, J.; Amundsen, M.; de Paoli, M. Breastfeeding among Somali mothers living in Norway: Attitudes, practices and challenges. Women Birth 2016, 29, 487-493. [CrossRef]

67. Grewal, N.K.; Andersen, L.F.; Sellen, D.; Mosdøl, A.; Torheim, L.E. Breast-feeding and complementary feeding practices in the first 6 months of life among Norwegian-Somali and Norwegian-Iraqi infants: The InnBaKost survey. Public Health Nutr. 2016, 19, 703-715. [CrossRef] [PubMed]

68. Tyler, L.; Kirby, R.; Rogers, C. Infant feeding practices among Sudanese women now living in regional south east Queensland, Australia. Breastfeed. Rev. 2014, 22, 13-19.

69. Woldeghebriel, M.; Hromi-Fiedler, A.; Lartey, A.; Gallego-Perez, D.; Sandow, A.; Pérez-Escamilla, R. Length of time in Ghana is associated with the likelihood of exclusive breastfeeding among Liberian refugees living in Buduburam. Matern. Child Nutr. 2017, 13, e12363. [CrossRef]

70. Aakre, I.; Strand, T.A.; Bjøro, T.; Norheim, I.; Barikmo, I.; Ares, S.; Alcorta, M.D.; Henjum, S. Thyroid function among breastfed children with chronically excessive iodine intakes. Nutrients 2016, 8, 398. [CrossRef]

71. Aakre, I.; Lilleengen, A.M.; Lerseth Aarsand, M.; Strand, T.A.; Barikmo, I.; Henjum, S. Infant feeding practices in the Saharawi refugee camps Algeria, a cross-sectional study among children from birth to six months of age. Int. Breastfeed. J. 2016, 12, 8. [CrossRef]

72. Montero, M.D.P.; Mora-Urda, A.I.; Anzid, K.; Cherkaoui, M.; Marrodan, M.D. Diet quality of Moroccan adolescents living in Morocco and in Spain. J. Biosoc. Sci. 2017, 49, 173-186. [CrossRef]

73. Rätsch, I.M.; Catassi, C. Coeliac disease: A potentially treatable health problem of Saharawi refugee children. Bull. World Health Organ. 2001, 79, 542-545.

74. Toselli, S.; Zaccagni, L.; Celenza, F.; Albertini, A.; Gualdi-Russo, E. Risk factors of overweight and obesity among preschool children with different ethnic background. Endocrine 2015, 49, 717-725. [CrossRef]

75. Grewal, N.K.; Andersen, L.F.; Kolve, C.S.; Kverndalen, I.; Torheim, L.E. Food and nutrient intake among 12-month-old NorwegianSomali and Norwegian-Iraqi infants. Nutrients 2016, 8, 602. [CrossRef] [PubMed]

76. Mescher-Benbenek, M.; Garwick, A.W. Enablers and barriers to dietary practices contributing to bone health among early adolescent Somali girls living in Minnesota. J. Spec. Pediatr. Nurs. 2012, 17, 205-214. [CrossRef]

77. Dharod, J.M.; Croom, J.E. Child hunger: Its prevalence and association with body mass index and dietary intake among Somali refugee children in the United States. NAPA Bull. 2010, 34, 126-140. [CrossRef]

78. Hadley, C.; Sellen, D. Food security and child hunger among recently resettled Liberian refugees and asylum seekers: A pilot study. J. Immigr. Minor. Health 2006, 8, 369-375. [CrossRef] [PubMed]

79. Mulugeta, W.; Glick, M.; Min, J.; Xue, H.; Noe, F.N.; Wang, Y. Longitudinal changes and high-risk subgroups for obesity and overweight/obesity among refugees in Buffalo, NY, 2004-2014. J. Racial Ethn. Health Dispar. 2018, 5, 187-194. [CrossRef]

80. Renzaho, A.M.N.; Swinburn, B.; Burns, C. Maintenance of traditional cultural orientation is associated with lower rates of obesity and sedentary behaviours among African migrant children to Australia. Int. J. Obes. 2008, 32, 594-600. [CrossRef]

81. Renzaho, A.M.N.; Gibbons, C.; Swinburn, B.; Jolley, D.; Burns, C. Obesity and undernutrition in sub-Saharan African immigrant and refugee children in Victoria, Australia. Asia Pac. J. Clin. Nutr. 2006, 15, 482-490. [PubMed]

82. Stellinga-Boelen, A.; Storm, H.; Wiegersma, P.; Bijleveld, C.; Verkade, H. Iron deficiency among children of asylum seekers in the Netherlands. J. Pediatr. Gastroenterol. Nutr. 2007, 45, 591-595. [CrossRef]

83. Kaufman-Shriqui, V.; Fraser, D.; Friger, M.; Bilenko, N.; Vardi, H.; Abu-Saad, K.; Elhadad, N.; Mor, K.; Feine, Z.; Shahar, D.R. Factors associated with childhood overweight and obesity among acculturated and new immigrants. Ethn. Dis. 2013, 23, 329-335. 
84. Hintzpeter, B.; Scheidt-Nave, C.; Müller, M.J.; Schenk, L.; Mensink, G.B.M. Higher prevalence of vitamin d deficiency is associated with immigrant background among children and adolescents in Germany. J. Nutr. 2008, 138, 1482-1490. [CrossRef]

85. McGillivray, G.; Skull, S.A.; Davie, G.; Kofoed, S.E.; Frydenberg, A.; Rice, J.; Cooke, R.; Carapetis, J. High prevalence of asymptomatic vitamin D and iron deficiency in east African immigrant children and adolescents living in a temperate climate. Arch. Dis. Child. 2007, 92, 1088-1093. [CrossRef]

86. Sheikh, M.; Wang, S.; Pal, A.; MacIntyre, C.R.; Wood, N.; Gunesekera, H. Vitamin D deficiency in refugee children from conflict zones. J. Immigr. Minor. Health 2011, 13, 87-93. [CrossRef]

87. Beukeboom, C.; Arya, N. Prevalence of nutritional deficiencies among populations of newly arriving government assisted refugee children to Kitchener/Waterloo, Ontario, Canada. J. Immigr. Minor. Health 2018, 20, 1317-1323. [CrossRef]

88. Khayri, H.O.; Munee, S.E.; Ahmed, S.B.; Osman, M.A.; Babiker, E.E. Assessment of the nutritional status of Sudanese primary school pupils in Riyadh City, Kingdom of Saudi Arabia. J. Immigr. Minor. Health 2016, 18, 28-33. [CrossRef]

89. Bern, C.; Nathanail, L. Is mid-upper-arm circumference a useful tool for screening in emergency settings? J. Immigr. Minor. Health 1995, 345, 631-633. [CrossRef]

90. Reifen, R.; Haftel, L.; Manor, G.; Sklan, D.; Edris, M.; Khoshoo, V.; Ghebremeskel, K. Ethiopian-born and native Israeli school children have different growth patterns. Nutrition 2003, 19, 427-431. [CrossRef]

91. Polonsky, J.A.; Ronsse, A.; Ciglenecki, I.; Rull, M.; Porten, K. High levels of mortality, malnutrition, and measles, among recently-displaced Somali refugees in Dagahaley camp, Dadaab refugee camp complex, Kenya. Confl. Health 2013, 7, 1. [CrossRef] [PubMed]

92. Seal, A.J.; Creeke, P.I.; Mirghani, Z.; Abdalla, F.; McBurney, R.P.; Pratt, L.S.; Brookes, D.; Ruth, L.J.; Machand, E. Iron and vitamin A deficiency in long-term African refugees. J. Nutr. 2005, 135, 808-813. [CrossRef]

93. Tumwine, J.K.; Obala, A.A. Nutrition status of children in Kasese district at the Uganda-Congo border. East Afr. Med. J. 2002, 79, 427-434. [CrossRef] [PubMed]

94. Renzaho, A.M.N.; Halliday, J.A.; Mellor, D.; Green, J. The healthy migrant families initiative: Development of a culturally competent obesity prevention intervention for African migrants. BMC Public Health 2015, 15, 272. [CrossRef]

95. Tondeur, M.C.; Salse, U.N.; Wilkinson, C.; Spiegel, P.; Seal, A.J. Rapid acceptability and adherence testing of a lipid-based nutrient supplement and a micronutrient powder among refugee children and pregnant and lactating women in Algeria. Public Health Nutr. 2016, 19, 1852-1861. [CrossRef]

96. Lopriore, C.; Guidoum, Y.; Briend, A.; Branca, F. Spread fortified with vitamins and minerals induces catch-up growth and eradicates severe anemia in stunted refugee children aged 3-6 y. Am. J. Clin. Nutr. 2004, 80, 973-981. [CrossRef] [PubMed]

97. Seal, A.; Kafwembe, E.; Kassim, I.A.; Hong, M.; Wesley, A.; Wood, J.; Abdalla, F.; van den Briel, T. Maize meal fortification is associated with improved vitamin A and iron status in adolescents and reduced childhood anaemia in a food aid-dependent refugee population. Public Health Nutr. 2008, 11, 720-728. [CrossRef] [PubMed]

98. Taylor, W.R. An evaluation of supplementary feeding in Somali refugee camps. Int. J. Epidemiol. 1983, 12, 433-436. [CrossRef] [PubMed]

99. Ndemwa, P.; Klotz, C.L.; Mwaniki, D.; Sun, K.; Muniu, E.; Andango, P.; Owigar, J.; Rah, J.H.; Kraemer, K.; Spiegel, P.B.; et al. Relationship of the availability of micronutrient powder with iron status and hemoglobin among women and children in the Kakuma Refugee Camp, Kenya. Food Nutr. Bull. 2011, 32, 286-291. [CrossRef]

100. Renzaho, A.; Renzaho, C. In the shadow of the volcanoes: The impact of intervention on the nutrition and health status of Rwandan refugee children in Zaire two years on from the exodus. Nutr. Diet 2003, 60, 85-91.

101. Aakre, I.; Henjum, S.; Folven Gjengedal, E.L.; Haugstad, C.R.; Vollset, M.; Moubarak, K.; Ahmed, T.S.; Alexander, J.; Kjellevoid, M.; Molin, M. Trace element concentrations in drinking water and urine among Saharawi women and young children. Toxics 2018, 6, 40. [CrossRef] [PubMed]

102. Dawson-Hahn, E.E.; Pak-Gorstein, S.; Hoopes, A.J.; Matheson, J. Comparison of the nutritional status of overseas refugee children with low income children in Washington State. PLoS ONE 2016, 11, e0147854. [CrossRef]

103. Ercolini, D.; Francavilla, R.; Vannini, L.; De Filippis, F.; Capriati, T.; Di Cagno, R.; Lacono, G.; De Angelis, M.; Gobbetti, M. From an imbalance to a new imbalance: Italian-style gluten-free diet alters the salivary microbiota and metabolome of African celiac children. Sci. Rep. 2015, 5, 18571. [CrossRef] [PubMed]

104. Paardekooper, B.; de Jong, J.T.V.M.; Hermanns, J.M.A. The psychological impact of war and the refugee situation on south Sudanese children in refugee camps in Northern Uganda: An exploratory study. J. Child Psychol. Psychiatry 1999, 40, 529-536. [CrossRef]

105. Peltzer, K. Trauma and mental health problems of Sudanese refugees in Uganda. Cent. Afr. J. Med. 1999, 45, 110-114. [CrossRef]

106. Völkl-Kernstock, S.; Völkl-Kernstock, S.; Karnik, N.; Karnik, N.; Mitterer-Asadi, M.; Mitterer-Asadi, M. Responses to conflict, family loss and flight: Posttraumatic stress disorder among unaccompanied refugee minors from Africa. Neuropsychiatry 2014, 28, 6-11. [CrossRef] [PubMed]

107. Aviad-Wilchek, Y.; Levy, I.; Ben-David, S. Readiness to use psychoactive substances among second-generation adolescent immigrants and perceptions of parental immigration-related trauma. Subst. Use Misuse 2017, 52, 1646-1655. [CrossRef] [PubMed]

108. Walsh, S.D.; Edelstein, A.; Vota, D. Suicidal ideation and alcohol use among Ethiopian adolescents in Israel. Eur. Psychol. 2012, 17, 131-142. [CrossRef] 
109. Wilchek-Aviad, Y. Meaning in life and suicidal tendency among immigrant (Ethiopian) youth and native-born Israeli Youth. J. Immigr. Minor. Health 2015, 17, 1041-1048. [CrossRef] [PubMed]

110. Meyer, S.R.; Steinhaus, M.; Bangirana, C.; Onyango-Mangen, P.; Stark, L. The influence of caregiver depression on adolescent mental health outcomes: Findings from refugee settlements in Uganda. BMC Psychiatry 2017, 17, 405. [CrossRef]

111. Meyer, S.R.; Meyer, E.; Bangirana, C.; Mangen, P.O.; Stark, L. Protection and well-being of adolescent refugees in the context of a humanitarian crisis: Perceptions from South Sudanese refugees in Uganda. Soc. Sci. Med. 2019, 221, 79-86. [CrossRef] [PubMed]

112. Jensen, T.K.; Fjermestad, K.W.; Granly, L.; Wilhelmsen, N.H. Stressful life experiences and mental health problems among unaccompanied asylum-seeking children. Clin. Child Psychol. Psychiatry 2015, 20, 106-116. [CrossRef]

113. Zwi, K.; Woodland, L.; Williams, K.; Palasanthiran, P.; Rungan, S.; Jaffe, A.; Woolfenden, S. Protective factors for social-emotional well-being of refugee children in the first three years of settlement in Australia. Arch. Dis. Child. 2018, 103, 261-268. [CrossRef] [PubMed]

114. Stevens, G.W.J.M.; Thijs, J. Perceived group discrimination and psychological well-being in ethnic minority adolescents. J. Appl. Soc. Psychol. 2018, 48, 559-570. [CrossRef]

115. Beiser, M.; Taa, B.; Fenta-Wube, H.; Baheretibeb, Y.; Pain, C.; Araya, M. A comparison of levels and predictors of emotional problems among preadolescent Ethiopians in Addis Ababa, Ethiopia, and Toronto, Canada. Transcult. Psychiatry 2012, 49, 651-677. [CrossRef]

116. Astell-Burt, T.; Maynard, M.J.; Lenguerrand, E.; Harding, S. Racism, ethnic density and psychological well-being through adolescence: Evidence from the determinants of adolescent social well-being and health longitudinal study. Ethn. Health 2012, 17, 71-87. [CrossRef]

117. Stevens, G.W.J.; Vollebergh, W.A.; Pels, T.V.; Crijnen, A.A. Problem behavior and acculturation in Moroccan immigrant adolescents in the Netherlands. J. Cross Cult. Psychol. 2007, 38, 310-317. [CrossRef]

118. Abdullahi, I.; Kruger, E.; Tennant, M. Service access and perceptions for Somali Australian migrants at risk of autism. Int. J. Migr. Health Soc. Care 2017, 13, 119-125. [CrossRef]

119. Goldblatt, H.; Rosenblum, S. Navigating among worlds: The experience of Ethiopian adolescents in Israel. J. Adolesc. Res. 2007, 22, 585-611. [CrossRef]

120. Ndengeyingoma, A.; de Montigny, F.; Miron, J.M. Development of personal identity among refugee adolescents: Facilitating elements and obstacles. J. Child Health Care 2013, 18, 369-377. [CrossRef]

121. Inguglia, C.; Musso, P. Intercultural profiles and adaptation among immigrant and autochthonous adolescents. Eur. J. Psychol. 2015, 11, 79-99. [CrossRef] [PubMed]

122. Sanchez-Cao, E.; Kramer, T.; Hodes, M. Psychological distress and mental health service contact of unaccompanied asylumseeking children. Child Care Health Dev. 2013, 39, 651-659. [CrossRef]

123. Iyakaremye, I.; Mukagatare, C. Forced migration and sexual abuse: Experience of Congolese adolescent girls in Kigeme refugee camp, Rwanda. Health Psychol. Rep. 2016, 4, 261-271. [CrossRef]

124. Williams, T.P.; Chopra, V.; Chikanya, S.R. "It isn't that we're prostitutes": Child protection and sexual exploitation of adolescent girls within and beyond refugee camps in Rwanda. Child Abus. Negl. 2018, 86, 158-166. [CrossRef]

125. Warria, A. Challenges in assistance provision to child victims of transnational trafficking in South Africa. Eur. J. Soc. Work 2018, 21, 710-723. [CrossRef]

126. Berman, H. Stories of growing up amid violence by refugee children of war and children of battered women living in Canada. J. Nurs. Scholarsh. 1999, 31, 57-63. [CrossRef] [PubMed]

127. Paalman, C.H.; van Domburgh, L.; Stevens, G.W.; Doreleijers, T.A.H. Individual, family and offence characteristics of high risk childhood offenders: Comparing non-offending, one-time offending and re-offending Dutch-Moroccan migrant children in the Netherlands. Child Adolesc. Psychiatry Ment. Health 2011, 5, 33. [CrossRef]

128. Ravid, C.; Spitzer, A.; Tamir, B.; Granot, M.; Noam, R. Internal body perceptions of Ethiopian Jews who emigrated to Israel. West. J. Nurs. Res. 1995, 17, 631-646. [CrossRef] [PubMed]

129. Stevens, G.W.J.M.; Pels, T.; Bengi-Arslan, L.; Verhulst, F.C.; Vollebergh, W.A.M.; Crijnen, A.A.M. Parent, teacher and self-reported problem behavior in the Netherlands. Soc. Psychiatry Psychiatr. Epidemiol. 2003, 38, 576-585. [CrossRef] [PubMed]

130. Stevens, G.W.J.M.; Veen, V.C.; Vollebergh, W.A.M. Psychological acculturation and juvenile delinquency: Comparing Moroccan immigrant families from a general and pretrial detention population. Cult. Divers. Ethn. Minor. Psychol. 2014, 20, $254-265$. [CrossRef] [PubMed]

131. Zlot, A. Body-perception among Ethiopian-Israeli teenage girls. Int. J. Adolesc. Med. Health 1999, 11, 61-92. [CrossRef]

132. Harding, S.; Boroujerdi, M.; Santana, P.; Cruickshank, J. Decline in, and lack of difference between, average birth weights among African and Portuguese babies in Portugal. Int. J. Epidemiol. 2006, 35, 270-276. [CrossRef]

133. Harding, S.; Santana, P.; Cruickshank, J.K.; Boroujerdi, M. Birth weights of Black African babies of migrant and nonmigrant mothers compared with those of babies of European mothers in Portugal. Ann. Epidemiol. 2006, 16, 572-579. [CrossRef] [PubMed]

134. Racape, J.; De Spiegelaere, M.; Alexander, S.; Dramaix, M.; Buekens, P.; Haelterman, E. High perinatal mortality rate among immigrants in Brussels. Eur. J. Public Health 2010, 20, 536-542. [CrossRef] [PubMed]

135. Jamieson, D.J.; Meikle, S.F.; Hillis, S.D.; Mtsuko, D.; Mawji, S.; Duerr, A. An evaluation of poor pregnancy outcomes among Burundian refugees in Tanzania. JAMA 2000, 283, 397-402. [CrossRef] [PubMed] 
136. Vang, Z.M. Infant mortality among the Canadian-born offspring of immigrants and non-immigrants in Canada: A populationbased study. Popul. Health Metr. 2016, 14, 32-47. [CrossRef]

137. Simeoni, S.; Frova, L.; De Curtis, M. Inequalities in infant mortality in Italy. Ital. J. Pediatr. 2019, 45, 11-18. [CrossRef]

138. Hargreaves, J.R.; Collinson, M.A.; Kahn, K.; Clark, S.J.; Tollman, S.M. Childhood mortality among former Mozambican refugees and their hosts in rural South Africa. Int. J. Epidemiol. 2004, 33, 1271-1278. [CrossRef]

139. Essén, B.; Hanson, B.S.; Östergren, P.O.; Lindquist, P.G.; Gudmundsson, S. Increased perinatal mortality among sub-Saharan immigrants in a city-population in Sweden. Acta Obstet. Gynecol. Scand. 2000, 79, 737-743. [CrossRef]

140. Juárez, S.P.; Revuelta-Eugercios, B.A. Too heavy, too late: Investigating perinatal health outcomes in immigrants residing in Spain. A cross-sectional study (2009-2011). J. Epidemiol. Community Health 2014, 68, 863-868. [CrossRef]

141. Legg, S.; Davies, A.M.; Prywes, R.; Sterk, V.V.; Weiskopf, P. Patterns of low birth weight in west Jerusalem with special reference to maternal origin. Br. J. Prev. Soc. Med. 1970, 24, 89-96. [CrossRef]

142. Racape, J.; Schoenborn, C.; Sow, M.; Alexander, S.; De Spiegelaere, M. Are all immigrant mothers really at risk of low birth weight and perinatal mortality? The crucial role of socio-economic status. BMC Pregnancy Childbirth 2016, 16, 75-85. [CrossRef]

143. Yudkin, P.L.; Harlap, S.; Baras, M. High birthweight in an ethnic group of low socioeconomic status. BJOG 1983, 90, 291-296. [CrossRef] [PubMed]

144. Agudelo-Suárez, A.A.; Ronda-Pérez, E.; Gil-González, D.; González-Zapata, L.I.; Regidor, E. Relationship in Spain of the length of the gestation and the birth weight with mother's nationality during the period 2001-2005. Rev. Esp. Salud Publica 2009, 83, 331-337. [CrossRef] [PubMed]

145. Buekens, P.; Masuy-Stroobant, G.; Delvaux, T. High birthweights among infants of North African immigrants in Belgium. Am. J. Public Health 1998, 88, 808-811. [CrossRef]

146. Vahratian, A.; Buekens, P.; Delvaux, T.; Boutsen, M.; Wang, Y.; Kupper, L.L. Birthweight differences among infants of north African immigrants and Belgians in Belgium. Eur. J. Public Health 2004, 14, 381-383. [CrossRef]

147. Johnson, E.B.; Reed, S.D.; Hitti, J.; Batra, M. Increased risk of adverse pregnancy outcome among Somali immigrants in Washington State. Am. J. Obstet. Gynecol. 2005, 193, 475-482. [CrossRef]

148. Flynn, P.M.; Foster, E.M.; Brost, B.C. Indicators of acculturation related to Somali refugee women's birth outcomes in Minnesota. J. Immigr. Minor. Health 2011, 13, 224-231. [CrossRef] [PubMed]

149. Ortiz-Echevarria, L.; Greeley, M.; Bawoke, T.; Zimmerman, L.; Robinson, C.; Schlecht, J. Understanding the unique experiences, perspectives and sexual and reproductive health needs of very young adolescents: Somali refugees in Ethiopia. Confl. Health 2017, 11, 26-34. [CrossRef]

150. Gaspar, T.; Matos-Gaspar, M. Adolescent's lifestyles, ethnicity and socioeconomic status in Portugal. J. Poverty 2009, 13, 49-57.

151. Essén, B.; Bödker, B.; Sjöberg, N.O.; Gudmundsson, S.; Östergren, P.O.; Langhoff-Roos, J. Is there an association between female circumcision and perinatal death? Bull. World Health Organ. 2002, 80, 629-632.

152. Macipe-Costa, R.; Macipe-Costa, R.; García-Sanchez, N.; García-Sanchez, N.; Gimeno-Feliu, L.; Gimeno-Feliu, L.; NavarraVicente, B.; Jimenez-Hereza, J.M.; Moneo-Hernandez, I.M.; Castillo-Laita, J.A.; et al. Non-therapeutic male circumcision performed on immigrant children from Africa in Spain. Int. J. Public Health 2014, 59, 351-358. [CrossRef] [PubMed]

153. Pruitt, C.N.; Reese, C.S.; Grossardt, B.R.; Shire, A.M.; Creedon, D.J. Completion of the human papillomavirus vaccination series lags in Somali adolescents. J. Low. Genit. Tract Dis. 2013, 17, 280-288. [CrossRef]

154. Vang, Z.M.; Elo, I.T. Exploring the health consequences of majority-minority neighborhoods: Minority diversity and birthweight among native-born and foreign-born blacks. Soc. Sci. Med. 2013, 97, 56-65. [CrossRef]

155. Mor, Z.; Amit Aharon, A.; Sheffer, R.; Nehama, H. Growth, developmental achievements and vaccines timeliness of undocumented migrant children from Eritrea compared with Israelis. PLoS ONE 2018, 13, e0193219. [CrossRef]

156. Sarafoglou, K.; Bentler, K.; Gaviglio, A.; Redlinger-Grosse, K.; Anderson, C.; McCann, M.; Bloom, B.; Babovic-Vuksanovic, D.; Gavrillow, D.; Berry, S.A. High incidence of profound biotinidase deficiency detected in newborn screening blood spots in the Somalian population in Minnesota. J. Inherit. Metab. Dis. 2009, 32, 169-173. [CrossRef]

157. Goel, K.M.; Thomson, R.B.; Sweet, E.M.; Halliday, S. Growth of immigrant children in the centre of Glasgow. Scott. Med. J. 1981, 26, 340-345. [CrossRef]

158. Kamer, A.; Zohar, A.; Youngmann, R.; Diamond, G.; Inbar, D.; Senecky, Y. A prevalence estimate of pervasive developmental disorder among Immigrants to Israel and Israeli natives. Soc. Psychiatry Psychiatr. Epidemiol. 2004, 39, 141-145. [CrossRef] [PubMed]

159. Barnevik-Olsson, M.; Gillberg, C.; Fernell, E. Prevalence of autism in children of Somali origin living in Stockholm: Brief report of an at-risk population. Dev. Med. Child Neurol. 2010, 52, 1167-1168. [CrossRef]

160. Barnevik-Olsson, M.; Gillberg, C.; Fernell, E. Prevalence of autism in children born to Somali parents living in Sweden: A brief report. Dev. Med. Child Neurol. 2008, 50, 598-601. [CrossRef] [PubMed]

161. Esler, A.; Hall-Lande, J.; Hewitt, A. Phenotypic characteristics of Autism Spectrum Disorder in a diverse sample of Somali and other children. J. Autism Dev. Disord. 2017, 47, 3150-3165. [CrossRef] [PubMed]

162. Fox, F.; Aabe, N.; Turner, K.; Redwood, S.; Rai, D. "It was like walking without knowing where I was going": A qualitative study of autism in a UK Somali migrant community. J. Autism Dev. Disord. 2017, 47, 305-315. [CrossRef] 
163. Wijtzes, A.; Jansen, W.; Jaddoe, V.; Moll, H.; Tiemeier, H.; Verhulst, F.; Hofman, A.; Mackenbach, J.; Raat, H. Ethnic background and television viewing time among 4-year-old preschool children: The generation R study. J. Dev. Behav. Pediatr. 2013, $34,63-71$. [CrossRef] [PubMed]

164. Mude, W.; Mwanri, L. Barriers to participation in physical activity among south Sudanese children in South Australia: Parents' perspectives. Fam. Community Health 2016, 39, 293-300. [CrossRef]

165. Thul, C.M.; LaVoi, N.M. Reducing physical inactivity and promoting active living: From the voices of East African immigrant adolescent girls. Qual. Res. Sport Exerc. Health 2011, 3, 211-237. [CrossRef]

166. Thul, C.M.; Eisenberg, M.E.; Larson, N.I.; Neumark-Sztainer, D. Physical activity patterns among Minnesota Somali adolescents. J. Phys. Act. Health 2015, 12, 1320-1326. [CrossRef] [PubMed]

167. Bakken, K.S.; Skjeldal, O.H.; Stray-Pedersen, B. Neonatal jaundice and the immigrant population: A comparison study at a low-risk maternity ward in Norway. Nord. J. Nurs. Res. 2015, 35, 165-171. [CrossRef]

168. Montanaro, M.; Colombatti, R.; Pugliese, M.; Migliozzi, C.; Zani, F.; Guerzoni, M.E.; Manoli, S.; Manara, R.; Meneghetti, G.; Rampazzo, P.; et al. Intellectual function evaluation of first generation immigrant children with sickle cell disease: The role of language and sociodemographic factors. Ital. J. Pediatr. 2013, 39, 36-43. [CrossRef] [PubMed]

169. Gorrab, A.A.; Fournier, A.; Bouaziz, A.A.; Spigelblatt, L.; Scuccimarri, R.; Mrabet, A.; Dahdah, N. Incidence rate and epidemiological and clinical aspects of Kawasaki disease in children of Maghrebi origin in the Province of Quebec, Canada, compared to the country of origin. Glob. Pediatr. Health 2016, 3, 1-8. [CrossRef]

170. Rovillé-Sausse, F. Growth rates of children of tilization African ancestry born to immigrant parents and of French children in Paris. Am. J. Hum. Biol. 1998, 10, 757-763. [CrossRef]

171. Davidovich, E.; Kooby, E.; Shapira, J.; Ram, D. The traditional practice of canine bud removal in the offspring of Ethiopian immigrants. BMC Oral Health 2013, 13, 34. [CrossRef] [PubMed]

172. Holan, G.; Mamber, E. Extraction of primary canine tooth buds: Prevalence and associated dental abnormalities in a group of Ethiopian Jewish children. Int. J. Paediatr. Dent. 1994, 4, 25-30. [CrossRef]

173. Cote, S.; Geltman, P.; Nunn, M.; Lituri, K.; Henshaw, M.; Garcia, R.I. Dental caries of refugee children compared with US children. Pediatrics 2004, 114, e733-e740. [CrossRef]

174. Quach, A.; Laemmle-Ruff, I.L.; Polizzi, T.; Paxton, G.A. Gaps in smiles and services: A cross-sectional study of dental caries in refugee-background children. BMC Oral Health 2015, 15, 10. [CrossRef]

175. Sarnat, H.; Cohen, S.; Gat, H. Changing patterns of dental caries in Ethiopian adolescents who immigrated to Israel. Community Dent. Oral Epidemiol. 1987, 15, 286-288. [CrossRef] [PubMed]

176. Sgan-Cohen, H.D.; Steinberg, D.; Zusman, S.P.; Sela, M.N. Dental caries and its determinants among recent immigrants from rural Ethiopia. Community Dent. Oral Epidemiol. 1992, 20, 338-342. [CrossRef] [PubMed]

177. Davidovich, E.; Kooby, E.; Shapira, J.; Ram, D. Oral hygiene habits, dental home, and toothbrushing among immigrant and native low socioeconomic class populations. J. Clin. Pediatr. Dent. 2013, 37, 341-344. [CrossRef] [PubMed]

178. Amin, M.; Perez, A.; Nyachhyon, P. Parental awareness and dental attendance of children among African immigrants. J. Immigr. Minor. Health 2015, 17, 132-138. [CrossRef] [PubMed]

179. Almerich-Silla, J.M.; Montiel-Company, J.M.; Ruiz-Miravet, A. Caries and dental fluorosis in a western Saharan population of refugee children. Eur. J. Oral Sci. 2008, 116, 512-517. [CrossRef] [PubMed]

180. Svensson, I.; Gustafsson, J.; Matsson, L.; Uleskog, E.; Molla, N.; Kahlmeter, A.; Matsson, L. Oral condition and background factors in Somali immigrant children newly arrived in Sweden. Swed. Dent. J. 2016, 40, 153-164.

181. Amin, M.; Perez, A. Is the wait-for-patient-to-come approach suitable for African newcomers to Alberta, Canada? Community Dent. Oral Epidemiol. 2012, 40, 523-531. [CrossRef] [PubMed]

182. Metsäniitty, M.; Waltimo-Sirén, J.; Ranta, H.; Fieuws, S.; Thevissen, P. Dental age estimation in Somali children and sub-adults combining permanent teeth and third molar development. Int. J. Leg. Med. 2019, 133, 1207-1215. [CrossRef]

183. Obeng, C.S. Dental care issues for African immigrant families of preschoolers. Early Child. Res. Pract. 2008, 10, 1-5.

184. Vered, Y.; Schwarts, N.; Mann, J.; Sgan-Cohen, H.D. Periodontal health among recent immigrants from Quara, rural Ethiopia and indications for periodontal health care. Int. Dent. J. 2003, 53, 92-96. [CrossRef]

185. Patel, A.R.; Zietlow, J.; Jacobson, R.M.; Poland, G.A.; Juhn, Y.J. Asthma and the immune response to MMR vaccine viruses in Somali immigrant children: A cross-sectional retrospective cohort study. Prim. Care Respir. J. 2013, 22, 278-283. [CrossRef]

186. Shani, M.; Band, Y.; Kidon, M.I.; Segel, M.J.; Rosenberg, R.; Nakar, S.; Vinker, S. The second generation and asthma: Prevalence of asthma among Israeli born children of Ethiopian origin. Respir. Med. 2013, 107, 519-523. [CrossRef]

187. Veenstra-van Schie, M.T.M.; Coenen, K.; Koopman, H.M.; Versteegh, F.G.A. Higher perceived HRQoL in Moroccan children with asthma and their parents. Pan Afr. Med. J. 2015, 21, 18-22. [CrossRef]

188. Bennet, R.; Eriksson, M. Tuberculosis infection and disease in the 2015 cohort of unaccompanied minors seeking asylum in Northern Stockholm, Sweden. Infect. Dis. 2017, 49, 501-506. [CrossRef]

189. Chemtob, D.; Weiler-Ravell, D.; Leventhal, A.; Bibi, H. Epidemiologic characteristics of pediatric active tuberculosis among immigrants from high to low tuberculosis-endemic countries: The Israeli experience. Isr. Med. Assoc. J. 2006, 8, 21-26.

190. Lucas, M.; Nicol, P.; McKinnon, E.; Whidborne, R.; Lucas, A.; Thambiran, A.; Burgner, D.; Waring, J.; French, M. A prospective large-scale study of methods for the detection of latent Mycobacterium tuberculosis infection in refugee children. Thorax 2010, 65, 442-448. [CrossRef] 
191. Nejat, S.; Bennet, R. Interferon-gamma release assays can effectively screen migrants for the tuberculosis infection, but urgent, active cases need clinical recognition. Acta Paediatr. 2016, 105, 671-675. [CrossRef]

192. Mor, Z.; Cedar, N.; Pinsker, G.; Bibi, H.; Grotto, I. Childhood tuberculosis in Israel: Epidemiological trends and treatment outcomes, 1999-2010. Eur. Respir. J. 2013, 41, 1157-1162. [CrossRef]

193. Paxton, G.A.; Rice, J.; Davie, G.; Carapetis, J.R.; Skull, S.A. East African immigrant children in Australia have poor tilization coverage. Paediatr. Child Health 2011, 47, 888-892. [CrossRef]

194. Chiappini, E.; Zaffaroni, M.; Bianconi, M.; Veneruso, G.; Grasso, N.; Garazzino, S.; Arancio, R.; Valentini, P.; Ficcadenti, A.; Da Riol, M.R.; et al. Italian tilization study found infectious and vaccine-preventable diseases in children adopted from Africa and recommends prompt medical screening. Acta Paediatr. 2018, 107, 1581-1586. [CrossRef]

195. Porter, J.D.; Gastellu-Etchegorry, M.; Navarre, I.; Lungu, G.; Moren, A. Measles outbreaks in the Mozambican refugee camps in Malawi: The continued need for an effective vaccine. Int. J. Epidemiol. 1990, 19, 1072-1077. [CrossRef]

196. St. Sauver, J.L.; Jacobson, R.M.; Vierkant, R.A.; Jacobsen, S.J.; Green, E.M.; Poland, G.A. Association of parental vaccination reports with measles, mumps, and rubella protective antibody levels: Comparison of Somali immigrant, Hispanic migrant, and US children in Rochester, Minn. Mayo Clin. Proc. 2002, 77, 241-245. [CrossRef]

197. Colombatti, R.; Palazzi, G.; Masera, N.; Notarangelo, L.D.; Bonetti, E.; Samperi, P.; Barone, A.; Perrotta, S.; Facchini, E.; Miano, M.; et al. Hydroxyurea prescription, availability and use for children with sickle cell disease in Italy: Results of a national multicenter survey. Ital. J. Pediatr. 2018, 65, e26774. [CrossRef]

198. Bawa, S.; Afolabi, M.; Abdelrahim, K.; Abba, G.; Ningi, A.; Tafida, S.Y.; Tegegne, S.G.; Warigon, C.; Nomhwange, T.; Umar, S.A.; et al. Transboundary nomadic population movement: A potential for import-export of poliovirus. BMC Public Health 2018, 18, 1316. [CrossRef]

199. Cadario, F.; Bruno, G.; Cerutti, F.; Savastio, S.; Tumini, S. Increasing prevalence and younger age at onset of type 1 diabetes in migrant than Italian children with type 1 diabetes: An emerging problem. Acta Diabetol. 2014, 51, 263-267. [CrossRef]

200. Hussen, H.I.; Moradi, T.; Persson, M. The risk of type 1 diabetes among offspring of immigrant mothers in relation to the duration of residency in Sweden. BMJ Open 2015, 38, 934-936. [CrossRef]

201. Vos, C.; Reeser, H.M.; Hirasing, R.A.; Bruining, G.J. Confirmation of high incidence of type 1 (insulin-dependent) diabetes mellitus in Moroccan children in the Netherlands. Diabet. Med. 1997, 14, 397-400. [CrossRef]

202. Oilinki, T.; Otonkoski, T.; Ilonen, J.; Knip, M.; Miettinen, P. Prevalence and characteristics of diabetes among Somali children and adolescents living in Helsinki, Finland. Pediatr. Diabetes 2012, 13, 176-180. [CrossRef]

203. Aakre, I.; Strand, T.A.; Moubarek, K.; Barikmo, I.; Henjum, S. Associations between thyroid dysfunction and developmental status in children with excessive iodine status. PLoS ONE 2017, 12, e0187241. [CrossRef]

204. Henjum, S.; Barikmo, I.; Gjerlaug, A.K.; Mohamed-Lehabib, A.; Oshaug, A.; Arne Strand, T.; Torheim, L.E. Endemic tiliz and excessive iodine in urine and drinking water among Saharawi refugee children. Public Health Nutr. 2010, 13, 1472-1477. [CrossRef] [PubMed]

205. Luboshitzky, R.; Dgani, Y.; Atar, S.; Qupty, G.; Tamir, A.; Flatau, E. Goiter prevalence in children immigrating from an endemic goiter area in Ethiopia to Israel. J. Pediatr. Endocrinol. 1995, 8, 123-125. [CrossRef] [PubMed]

206. Nudelman, A. Culture and health behaviour: The case of adolescent Ethiopian immigrants In Israel. Int. J. Adolesc. Med. Health 1999, 11, 3-20. [CrossRef] [PubMed]

207. Meyer-Weitz, A.; Oppong Asante, K.; Lukobeka, B.J. Healthcare service delivery to refugee children from the Democratic Republic of Congo living in Durban, South Africa: A caregivers' perspective. BMC Med. 2018, 16, 163. [CrossRef] [PubMed]

208. Soriano, E.; Ruiz, D.; Higginbottom, G. Health promotion in the Moroccan child population in Spain: The healthy child program. Procedia Soc. Behav. Sci. 2014, 132, 675-681. [CrossRef]

209. Zwi, K.; Rungan, S.; Woolfenden, S.; Woodland, L.; Palasanthiran, P.; Williams, K. Refugee children and their health, development and well-being over the first year of settlement: A longitudinal study. J. Trop. Pediatr. 2017, 53, 841-849. [CrossRef]

210. Cooke, R.; Murray, S.; Carapetis, J.; Rice, J.; Mulholland, N.; Skull, S. Demographics and utilisation of health services by paediatric refugees from East Africa: Implications for service planning and provision. Aust. Health Rev. 2004, 27, 40-45. [CrossRef]

211. Bennett, F.J.; Jelliffe, D.B. The health of immigrant babies in an East African town. Trop. Geogr. Med. 1965, 17, 213-224. [PubMed]

212. Plotinsky, R.N.; Straetemans, M.; Wong, L.Y.; Brown, M.J.; Dignam, T.; Dana Flanders, W.; Tehan, M.; Azziz-Baumgartner, E.; Dipentima, R.; Talbot, E.A. Risk factors for elevated blood lead levels among African refugee children in New Hampshire, 2004. Environ. Res. 2008, 108, 404-412. [CrossRef]

213. Corriveau-Bourque, C.; Bruce, A.A.K. The changing epidemiology of pediatric hemoglobinopathy patients in northern Alberta, Canada. J. Pediatr. Hematol. Oncol. 2015, 37, 595-599. [CrossRef]

214. McMahon, C.; Callaghan, C.O.; O’Brien, D.; Smith, O.P. The increasing prevalence of childhood sickle-cell disease in Ireland. Ir. J. Med. Sci. 2001, 170, 183-185. [CrossRef]

215. Oppenheim, C.E.; Axelrod, K.; Menyongai, J.; Chukwuezi, B.; Tam, A.; Henderson, D.C.; Borba, C.P.C. The HEAAL project: Applying Community-Based Participatory Research (CBPR) methodology in a health and mental health needs assessment with an African immigrant and refugee faith community in Lowell, Massachusetts. J. Public Health Manag. Pract. 2019, 25, E1-E6. [CrossRef]

216. Murray, K.E.; Mohamed, A.S.; Dawson, D.B.; Syme, M.; Abdi, S.; Barnack-Taviaris, J. Somali perspectives on physical activity: Photovoice to address barriers and resources in San Diego. Prog. Community Health Partnersh. 2015, 9, 83-90. [CrossRef] [PubMed] 
217. Collins, C.S.; Stockton, C.M. The central role of theory in qualitative research. Int. J. Qual. Methods 2018, 17, 1-10. [CrossRef]

218. Lynch, E.A.; Mudge, A.; Knowles, S.; Kitson, A.L.; Hunter, S.C.; Harvey, G. "There is nothing so practical as a good theory": A pragmatic guide for selecting theoretical approaches for implementation projects. BMC Health Serv. Res. 2018, 18, 857. [CrossRef] [PubMed]

219. Stewart, D.; Klein, S. The use of theory in research. Int. J. Clin. Pharm. 2016, 38, 615-619. [CrossRef]

220. UNICEF. Data Snapshot of Migrant and Displaced Children in Africa; United Nations: Geneva, Switzerland, 2019.

221. Statistics Canada. Diversity of Black Population in Canada-An Overview; Ethnicity, Language and Immigration Thematic Series; Statistics Canada: Ottawa, ON, Canada, 2019.

222. Odeniyi, A.O.; Embleton, N.; Ngongalah, L.; Akor, W.; Rankin, J. Breastfeeding beliefs and experiences of African immigrant mothers in high-income countries: A systematic review. Matern. Child Nutr. 2020, 16, e12970. [CrossRef]

223. Jakub, K.E.; Turk, M.T.; Fapohunda, A.; Zoucha, R. Cultural beliefs, perceptions, and practices of young adult offspring of African immigrants regarding healthy eating and activity. J. Transcult. Nurs. 2018, 29, 548-554. [CrossRef] [PubMed]

224. Cooper Brathwaite, A.; Lemonde, M. Health beliefs and practices of African immigrants in Canada. Clin. Nurs. Res. 2015, 25, 626-645. [CrossRef]

225. Kim, M.S.; Song, I.G.; An, A.R.; Kim, K.H.; Sohn, J.H.; Yang, S.W. Healthcare access challenges facing six African refugee mothers in South Korea: A qualitative multiple-case study. Korean J. Pediatr. 2017, 60, 138-144. [CrossRef] [PubMed]

226. Chekero, T.; Ross, F.C. "On paper" and "having papers": Zimbabwean migrant women's experiences in accessing healthcare in Giyani, Limpopo province, South Africa. Anthropol. S. Afr. 2018, 41, 41-54. [CrossRef]

227. Fatahi, N.; Krupic, F. Factors beyond the language barrier in providing health care to immigrant patients. Med. Arch. 2016, 70, 61-65. [CrossRef]

228. Mbanya, V.N.; Terragni, L.; Gele, A.A.; Diaz, E.; Kumar, B.N. Access to Norwegian healthcare system-Challenges for sub-Saharan African immigrants. Int. J. Equity Health 2019, 18, 125-138. [CrossRef] [PubMed]

229. Pérez-Urdiales, I.; Goicolea, I.; San Sebastián, M.; Irazusta, A.; Linander, I. Sub-Saharan African immigrant women's experiences of (lack of) access to appropriate healthcare in the public health system in the Basque Country, Spain. Int. J. Equity Health 2019, 18, 59-70. [CrossRef]

230. Berge, J.M.; Fertig, A.; Tate, A.; Trofholz, A.; Neumark-Sztainer, D. Who is meeting the Healthy People 2020 objectives?: Comparisons between racially/ethnically diverse and immigrant children and adults. Fam. Syst. Health 2018, 36, 451-470. [CrossRef]

231. Truong, M.; Paradies, Y.; Priest, N. Interventions to improve cultural competency in healthcare: A systematic review of reviews. BMC Health Serv. Res. 2014, 14, 99. [CrossRef] [PubMed]

232. World Health Organization (WHO). Child Health; World Health Organization Regional Office for Africa: Geneva, Switzerland, 2020.

233. UNICEF. A Deadly Journey for Children: The Migration Route from North Africa to Europe; United Nations: Geneva, Switzerland, 2017.

234. Markides, K.S.; Rote, S. The healthy immigrant effect and aging in the United States and other western countries. Gerontologist 2019, 59, 205-214. [CrossRef]

235. WHO. Universal Health Coverage. Key Facts. 2019. Available online: https://www.who.int/news-room/fact-sheets/detail/ universal-health-coverage-(uhc) (accessed on 1 March 2020). 